\title{
Luonto historiakuvan loimilangaksi? Luonnonympäristölle annetut merkitykset pohjoiskarjalaisessa matkailussa
}

Oona IImolahti, Itä-Suomen yliopisto, Historia- ja maantieteiden laitos

\begin{abstract}
Nature and culture are often seen as two separate entities in the travel industry. In this article, it is argued that nature is an essential part of human culture, and nature tourism should also be interpreted through cultural concepts. Cultural nature is addressed by examining the historical imaginaries used in the tourist attractions within the North Karelia Biosphere Reserve in Eastern Finland. The main scope of interest is how nature is implicated in the local narratives of the past, and how history and nature are intertwined in nature attractions such as national parks. The findings will be viewed with the help of a museological significance assessment, which enables the examination of the different meanings given to cultural nature in tourism. The cultural information about local nature and human traces of human life in nature can be regarded as enhancing the attractiveness of the area and as constituting an integral part of the nature experience. National parks can be seen as nature museums, which originally sought to preserve samples of virginal forests, thus representing the nature relationship of the previous generations. Nature, the key attraction of the area, is deeply connected with the local history culture and imaginaries of the exotic wilderness of Karelianism. The national romantic view bypasses to some extent the local experience and stories by emphasising the 19th-century national romantic artists and images related to historical Border Karelia.
\end{abstract}

Keywords: nature tourism, cultural nature, historical imaginaries, significance assessment, North Karelia 


\section{Johdanto}

Ennen kuin astut kansallispuistoon, lue, mikä on sen tarina. Luonto, joka muutenkin olisi silmiesi edessä lumoavan kaunis, muuttuu entistä kauniimmaksi ja entistä merkityksellisemmäksi. (Saari, 2017)

Menneisyyden tuotteistaminen ja esittäminen liitetään yleensä kulttuurimatkailuun, ja luontomatkailu koetaan kulttuurisista määreistä irrallisena ulkoiluna tai retkeilynä. Luontoa ei useinkaan ymmärretä osaksi historiakuvaa, vaan sitä pidetään ihmisestä erillisenä, oman logiikkansa mukaan toimivana järjestelmänä. Luonnonympäristössä sijaitsevat matkakohteet on kuitenkin mahdollista nähdä historian käytön ilmauksina. Suomalaiseen historiakulttuuriin sisältyy useita luontoon liittyviä oletuksia alkaen suomalaisten luonnonläheisyydestä ja tiiviistä luontosuhteesta (Knuuttila \& Piela, 2014), joiden voidaan ajatella sisältyvän myös 1800-luvulla luotuun selviytyjäkansamyyttiin (Ahonen, 2018). Etenkin metsäluonto on voimakas kulttuurinen symboli: se on yhtä aikaa salaperäisten voimien koti, raaka-ainevarasto, turisteille tuotteistettava ympäristö sekä talonpoikas- ja eräkulttuuriin sisältyvän metsäsuhteen pohja (von Bonsdorff, 2007, s. 44-45).

Historiakuva on se kokonaiskäsitys, joka menneisyyden ajanjaksosta, asiasta tai paikasta muodostuu, kun erilaiset tarinat, aikalaismuistelut ja tutkimukset yhdistyvät (Miettunen, 2009). Menneisyydelle annetaan merkityksiä, jolloin siitä tulee historiaa. Historiakulttuuri - tavat, joilla menneisyyttä koskevia mielikuvia muokataan - rakentuu paitsi kansallisesti myös paikallisesti. Luonnonympäristö vaikuttaa merkittävästi paikallisen historiakuvan rakentumiseen, onhan luonnonolosuhteiden katsottu olevan keskeinen alueellisen identiteetin rakennusaine (Paasi, 1986, s. 38). Historiakulttuuri muokkautuu yhteisöllisesti historiankirjoituksen, historia-aiheisten kulttuurituotteiden ja muistelukerronnan välisessä vuorovaikutuksessa (Ahonen, 2018). Mainittuja kulttuurituotteita ovat romaanit, muistomerkit, sadut, museot ja elokuvat, jopa nostalgia (Rantala, 2012, s. 14), mutta niitä voivat olla myös paikallisesti matkailua varten tuotettu historiallinen tieto ja mielikuvat.

Menneisyydestä puhuttaessa on tapana nähdä ero ihmisen historian ja luonnon historian välillä (Lähde, 2005). Luonto on jotain, joka on ollut ennen ihmistä, koskematonta ja pysyvää, vaikka todellisuudessa ihmisen hallitseman tilan vastapainoksi koettu villi erämaaluonto on kulttuurisena konstruktiona osa inhimillistä elinpiiriä (Richardson, 2001, 79-98; von Bonsdorff, 2007, s. 33-35; Williams, 2003). Luonnon ja ihmisen historian välille tehty ero tulee esille Karjalattaressa vuonna 1882 julkaistusta kirjeestä, jota on hyödynnetty myös ilomantsilaisen Möhkön ruukkimuseon historian tarinallistamisessa:

Ajattelepa nyt ajassa vajaata viisikymmentä vuotta takaperin. Me istumme samalla paikalla kuin nytkin, mutta mikä äärettömän jylhä ja kolkko erämaa ympäröi meitä silloin minne vaan silmämme käännämme. Ikivanhat kuuset ja hongat kohottavat taivaalle latvojaan, joissa tuuli hiljalleen humisee, johdattaen mielen - - hämärään muinoisaikaan, --jolloin ei yhdenkään ihmisen jalka tallaillut niiden sammaltuneita juuria. (Möhkön ruukki)

Kirjeessä kuvataan teollistumisen tunkeutumista syrjäseudulle, ihmisen muuttumista subjektiksi suhteessa luontoon. Neitseellinen esihistoriallinen aika on ohitse, ikihongat kaatuvat ryskyen, louhikot tasoittuvat, Möhkön kylä ja rautaruukki rakentuvat. Ihminen keskeyttää 
luonnon iäisyyselon valjastaen sen voimat omaan käyttöönsä ja herättäen kysymyksen, ovatko ihmisen ja luonnon historiat nyt erkautuneet.

\section{Tutkimusasetelma}

Tässä artikkelissa esitellään ja arvioidaan sitä, minkälaisia merkityksiä kulttuuriselle luonnolle on pohjoiskarjalaisessa historiakuvassa annettu ja miten tämä kuva on näkynyt aluetta koskevassa matkailupuheessa. Hypoteesina on, että luontokohteisiin liittyvät kulttuuri- ja asutushistorialliset tarinat ja kulttuurinen luonto ovat eräänlainen museokokoelma, jonka arvoa ei ole matkailuteollisuudessa vielä täysin ymmärretty. Tutkimusongelmaa valotetaan Pohjois-Karjalan biosfäärialueen ja sen alueella sijaitsevien Lieksan ja Ilomantsin kuntien matkailukohteiden kautta. ${ }^{1}$ Biosfäärialueet ovat Unescon vuonna 1971 lanseeraamaan Man and the Biosphere -ohjelmaan kuuluvia kestävän kehityksen mallialueita, joilla pyritään rakentamaan tieteellistä perustaa ihmisen ja luonnon väliselle suhteelle (Unesco). Suomessa alueita on kaksi, vuonna 1992 perustettu Pohjois-Karjalan biosfäärialue ja vuonna 1994 perustettu Saaristomeren biosfäärialue.

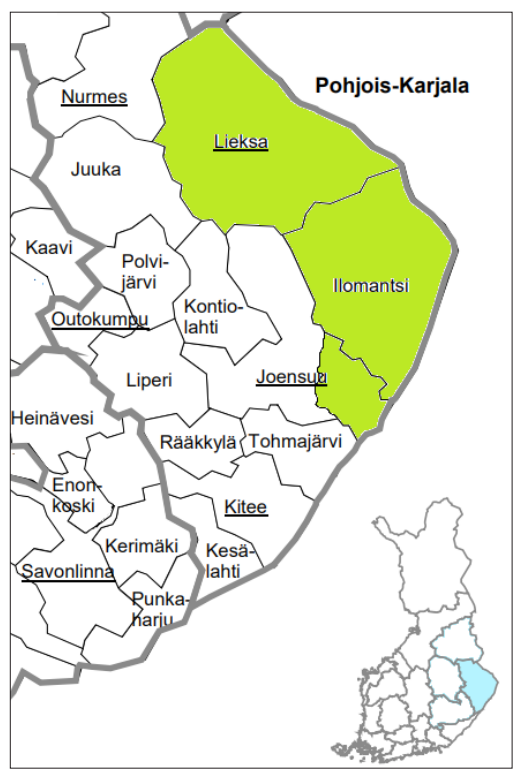

Kuva 1. Pohjois-Karjalan biosfäärialue. Pienessä kartassa näkyy koko Pohjois-Karjalan alue. Vaikka biosfäärialue rajautuu Lieksan, Ilomantsin ja Tuupovaaran alueille, on koko maakunta biosfäärihankkeen vaikutusaluetta.

Koska biosfäärialueen matkailu tukeutuu laajojen luonnonvaraisten alueiden varaan, nousee analyysissä keskeiseen rooliin kansallispuistojen merkitys osana alueen kulttuuriperintöä ja historiakuvaa. Seudulla sijaitsee kolme kansallispuistoa, useita muita suojelualueita sekä aktii-

1 Artikkeli on osa tutkimushanketta Lively Border. Nature Tourism and History Politics in the Finnish-Russian-Norwegian Border Region, jonka tarkoituksena on etsiä uusia tapoja tarkastella luonnon ja ihmisen välisiä suhteita matkailussa ja paikallisessa muistamisessa (http://www.uef.fi/fi/web/greenzoneproject). Itä-Suomen yliopistossa toimivan hankkeen johtajana on professori Maria Lähteenmäki ja hanketta rahoittaa Koneen Säätiö (nro 64737, 2017-2020). 
visesti toimivia kulttuurihistoriallisia kohteita. Ilomantsin ja Lieksan kunnilla on vahvat perinteet matkailun kehittämisessä, ja matkailusta on toisen maailmansodan jälkeen tullut tärkeä osa niiden elinkeinorakennetta (Piitulainen, 2014, s. 23-27, 41, 43). Paikallista historiakulttuuria tuottavat useat eri toimijat: kunnat, museot, yhdistykset, yrittäjät ja taiteilijat, ja matkailu on keskeinen motiivi historiakuvan verbalisoimiselle ja tuotteistamiselle. Unescon alaiseen ohjelmaan kuuluminen tuo sekä matkailuun että aineettoman luonnon- ja kulttuuriperinnön sanoittamiseen oman lisäarvonsa. Osana biosfäärialuetta kunnat ja pienemmät paikalliset toimijat ovat sitoutuneet kestävän kehityksen periaatteisiin ja ovat joutuneet näin ainakin teoriassa pohtimaan alueen ainutlaatuisen luonnon roolia ja merkitystä paikallisyhteisön elämässä. (Kareliabiosphere.)

Lähestymistavaltaan historiatieteellisen artikkelin teoreettisena viitekehyksenä on historian käytöstä ja historiakulttuurista käyty keskustelu. Historiakulttuurista tuli laajemman historiografisen kiinnostuksen kohde 1990-2000-luvun taitteessa. Aikalaiskeskustelijoiden mukaan akateemisen historiankirjoituksen tuli toimia vuorovaikutuksessa populaarin historiakulttuurin kanssa (Salmi, 2001, s. 135-137). Ranskalainen filosofi Paul Ricœur julkaisi vuonna 2000 teoksen La mémoire, l'histoire, l'oubli, jossa hän pohti historiankirjoituksen tasoja sekä muistamisen ja unohtamisen problematiikkaa. Ricœur puhui historiankirjoituksesta representaationa, jossa kertoja rakentaa juonellisen narratiivinsa oman aikansa lähtökohdista käsin. (Ricœur, 2000.) Ruotsalainen historioitsija Peter Aronsson on toivonut tutkijoilta avoimempaa suhdetta akateemisen maailman ulkopuolella avautuvaan historiakulttuuriin - siihen ei hänen mukaansa pitäisi suhtautua torjuvasti, vaan päinvastoin olisi tärkeää tarkastella siihen sisältyviä merkityksiä. (Aronsson, 2000, s. 15, 33; Aronsson, 2004.)

Historiakuvan rakentaminen on ennen kaikkea valintoja: tiettyjä piirteitä, tapahtumaketjuja tai aikakausia korostetaan, ja menneisyyden representaatioissa toistuvat kollektiiviset unohdukset (Aronsson, 2004, s. 200) ja yhteisesti hyväksytyt kertomukset. Kerronnan lähtökohdat ovat aina nykyisyyden tavoitteissa, ja tapa esittää menneisyyttä heijastelee esittäjän itsestään luomaa kuvaa. Tästä syystä menneisyyskuva muokkautuu aina tarpeen mukaan. (Petrisalo, 2001, s. 107.) Tämä ei kuitenkaan tarkoita, että kuva olisi vääristelty, eikä kaupallinen historiakulttuuri välttämättä merkitse historian väärinkäyttöä (Ilmonen, 2016, s. 15). Suuri osa historian esityksistä on puhuttuja, eivätkä historian rakentamiseen osallistu vain ammattihistorioitsijat vaan kaikki ihmiset (Kalela, 2010, s. 40-41). Tutkijoiden esitykset kilpailevat poliitikkojen, taiteilijoiden, kulttuurivaikuttajien ja tavallisten kansalaisten tuottaman historiakulttuurin kanssa. Kaikki historian esitykset ovat tekijänsä arvoista kertovia jälkiä, jotka asettuvat tulkinnan ja kerronnan ajalliseen jatkumoon. (Grönholm \& Sivula, 2010, s. 11-12; Ricœur, 2000.)

Analyysin tukena käytetään museo-objektien arvon määrittelyyn luotua metodologista apuvälinettä, merkitysanalyysiä (significance assessment, Russel \& Winkworth, 2009), joka soveltuu kulttuurin ilmausten tarkasteluun myös museomaailman ulkopuolella (Häyhä, Jantunen \& Paaskoski, 2015; Paaskoski, 2015). Jokainen matkailukohde, myös luonnonympäristö, on kulissi, joka kertoo tarinoita ja kantaa aineettomia merkityksiä. Siksi sitä voidaan analysoida samanlaisin määrein kuin museo-objektejakin. Tässä artikkelissa tarkastelun kohteena on kulttuurinen luonto ja sille matkailun kontekstissa annetut historialliset merkitykset. Kulttuurisella luonnol- 
la tarkoitetaan niitä merkityksiä ja käyttötapoja, joita ihminen on aikojen kuluessa antanut faunalle, flooralle, vesistöille, geologisille muodostelmille, koko biosfäärille. Merkitysanalyysissä objekti (tässä kulttuurinen luonto) nähdään tiedon, merkitysten ja aineellisen tai aineettoman kulttuurin ilmausten muodostamana kokonaisuutena. Menetelmän avulla pyritään löytämään objektin kulttuurinen arvo ja tavoittamaan niitä merkityksiä, joita sillä on yhteisöille. Tätä kautta myös paikallinen historia, kulttuuri ja ympäristö tulevat helpommin ymmärrettäviksi. (Russel \&Winkworth, 2009, s. 1.) Metodi on hedelmällinen tarkasteltaessa luonnonympäristön kulttuurisia ja historiallisia merkityksiä: laajentamalla näkökulmaa voidaan mahdollisesti tavoittaa piirteitä, jotka johtavat luonnonympäristön potentiaalin parempaan ymmärrykseen.

Merkitysanalyysin käyttö vaatii useita aihetta erilaisista näkökulmasta avaavia aineistokokonaisuuksia, jotta kohdetta voidaan valottaa mahdollisimman monipuolisesti. Useaa eriaikaista lähdettä käyttämällä pyritään löytämään merkityksiä, jotka kertovat kulttuurisen luonnon yhteyksistä paikallisiin historiallisiin taustakertomuksiin. Historiallinen lehdistöaineisto ja kirjallisuus muodostavat tässä tutkimuksessa yhden aineistokokonaisuuden. Niiden avulla valotetaan ilmiön juuria ja kulttuurisen luontosuhteen pysyviä ja muuttuvia elementtejä sekä niitä kulttuurisia merkityksiä, joita luontokohteiden identifioimiseen on aikanaan kytketty. Näitä aineistoja koskevat otannat on poimittu keskeisistä taitekohdista: 1920-luvulta, jolloin aiheeseen liittyvä keskustelu oli aktiivista luonnonsuojelulainsäädännön ja matkailussa tapahtuneiden muutosten vuoksi, sekä 1950-luvulta, jolloin rakennemuutoksen keskellä hahmoteltiin luontosuhteen uusia periaatteita ja luonnon hoitamisen sekä suojelun välistä muuttuvaa suhdetta (ks. esim. Pekurinen, 1997, Perttula, 2006). Keskeisiä julkaisuja ovat Matkailijayhdistyksen vuosikirja sekä 1950-luvulta Suomen Luonto, joka perustettiin 1940-luvun alussa Suomen Luonnonsuojeluyhdistyksen (myöhemmin Suomen luonnonsuojeluliitto) äänenkannattajaksi.

Toinen keskeinen aineistoryhmä on Suomalaisen Kirjallisuuden Seuran (SKS) vuonna 2013 toteuttama, Pohjois-Karjalan suojelualueita koskenut kansallispuistokeräys, jonka avulla voidaan arvioida luonnolle annettuja kulttuurisia merkityksiä luontomatkailijoiden näkökulmasta. Kävijöiden kokemukset biosfärialueen kolmesta kansallispuistosta kertovat, miten historia, luonnonympäristö ja kehollisuus kohteissa liikuttaessa yhdistyvät ja mitä merkityksiä matkailijat ovat kulttuurisesta luonnosta löytäneet.

Edellä mainittujen kahden aineistokokonaisuuden lisäksi hyödynnetään alueella matkailua varten tuotettua verkkomateriaalia, tutkimus- ja kaunokirjallisuutta, Metsähallituksen tutkimuksia sekä Itä-Suomen yliopiston Lively Border -hankkeessa vuonna 2017 Karjalan alueen museoille tehtyä haastatteluja ja Green Museum -verkkokyselyä (ks. Ilmolahti, Lähteenmäki, Karhu \& Osipov, 2018).

Artikkeli jakautuu kolmeen analyysilukuun: taustoitukseen, paikallisten luontokohteiden kulttuuristen piirteiden arviointiin sekä historiakuvan tarkasteluun. Ensimmäisessä luvussa kontekstoidaan luontomatkailun historiaa sekä suojelualueiden perustamiseen liittyviä motiiveja. Sen jälkeen syvennytään biosfäärialueella sijaitsevien luontokohteiden kulttuurihistoriallisiin ja kokemuksellisiin merkityksiin. Kolmannessa luvussa keskitytään matkailua varten tuotettuihin historiakuviin ja konstruktioihin sekä peilataan niitä luonnolle ja ympäristölle 
paikallisesti annettuihin merkityksiin. Artikkelin viimeisessä luvussa esitellään tutkimuksen tärkeimmät johtopäätökset.

\section{Sivistystä luontomuseosta - kulttuuri- ja luontomatkailun rajapintoja}

Matkailijat ovat yleensä elämys- ja kokemushakuisia, ja tämä pätee myös luontomatkailuun (Hallikainen, Sievänen, Tuulentie \& Tyrväinen, 2014). Tutkijat ovat paikantaneet modernin turistin synnyn 1920-luvulle, jolloin matkailun painopiste siirtyi miellyttävässä ilmanalassa lepäilystä elämysten hakemiseen (Syrjämaa, 2004, s. 183-185). Matkailuun vaikutti myös sen demokratisoituminen. Matkailijamäärät kasvoivat, kun vuoden 1922 työsopimuslain ja vuoden 1939 vuosilomalain ansiosta työväestökin pääsi osalliseksi lomanvietosta. Samalla kasvoi tarve lomienvieton moraalisen sääntelyyn; lomat toivottiin vietettävän sivistävässä ja tervehdyttävässä hengessä. (Anttila, 2005.) Kun teollisuustyöväestön vuosilomat vaiheittain pitenivät, luonnonympäristössä retkeilystä tuli luontevasti entistä suositumpaa.

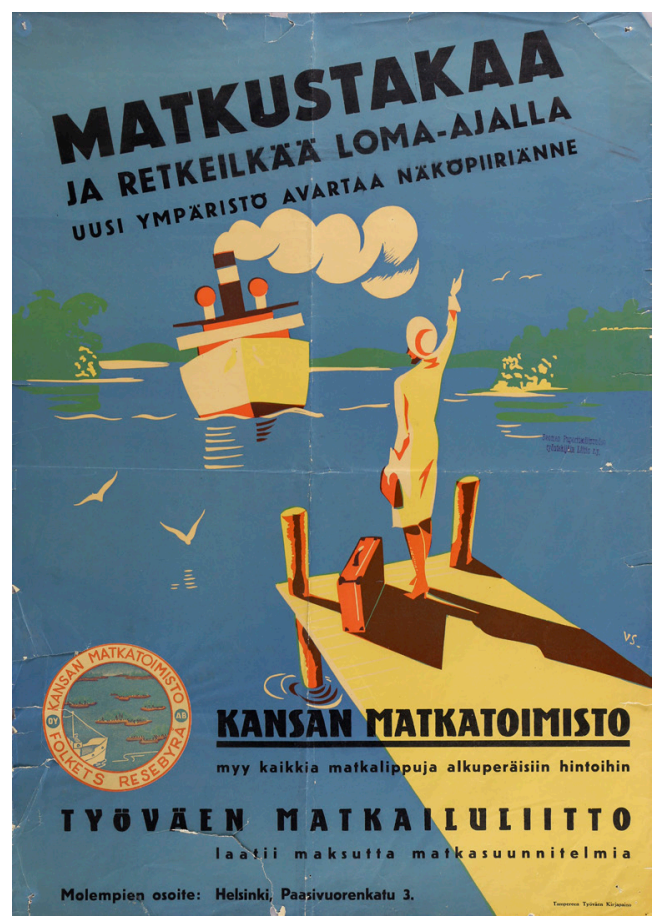

Kuva 2. Matkailijajoukot lisääntyivät lomalainsäädännön kehittyessä. Kulutusosuuskuntien Keskusliitto muistutti 1930-luvulla mahdollisuudesta avartaa näköaloja matkailun ja retkeilyn avulla. Kuva-aiheena oli suomalaisille tuttu vapaa-ajanvieton elementti, vesistö. (Kuva: Työväen Arkisto.)

Toisen maailmansodan jälkeinen rakennemuutos muutti entisestään matkailijoiden motiiveja: vähittäinen kaupungistuminen ja vapaa-ajan lisääntyminen lisäsivät liikunnallisen luonto- ja terveysmatkailun suosiota. Suomen Matkailijayhdistyksen toiminnanjohtaja Yrjö Soini totesi 
vuonna 1950, että yleistyvän matkailun tärkeimmät motiivit olivat käsi kädessä esiintyvät ihmisen aikaansaannokset ja koskematon luonto. Kiihkein kaipuu luontoon oli kaupunkilaisilla, ja yleisesti oli alettu kiinnostua kansallispuistoista ja luonnonsuojelualueista. Soinin mukaan oli tärkeää nähdä ihmisen kulttuuriset saavutukset luonnon taustaa vasten. (Soini, 1950, s. 15-16.)

Usein oletetaan, että matkailijat hakevat joko luonto- tai kulttuurielämyksiä. Käytännössä matkailijan motiiveja on mahdotonta luokitella puhtaisiin kategorioihin, ja luontokohteet ovat usein myös kulttuurikohteita (Edelheim, 2017, s. 54; Hovi, 2017, s. 64). Sosiologi René van der Duimin (2005, s. 17) mukaan turismi ei koskaan ole joko luontoon tai kulttuuriin suuntautuvaa vaan jotain siltä väliltä, ja juuri väliin jäävä on tutkimuksellisesti hedelmällistä. Luontomatkailu on kattokäsite, jonka perusoletus on, että kohteena ovat luonnonympäristön nähtävyydet (Rantala, 2017, s. 59). Historiaan liittyvä kulttuuriturismi taas on mielletty matkailuksi paikkoihin, joissa menneisyys on jollakin lailla tuotteistettu (Raivo, 2007, s. 269). Kulttuurikohteiksi ymmärretyt nähtävyydet ovat valintaprosesseissa päätyneet osaksi suojelemisen arvoista kulttuuriperintöä. Valintaprosessit linkittyvät oleellisesti matkailuun, sillä suojelu- tai perintökohteeksi päätyminen lisää paikan matkailullista arvoa. (Hovi, 2017, s. 65-67.)

Luonnonympäristössä liikkuessamme emme yleensä tule ajatelleeksi luonnon kokemiseen liittyviä kulttuurisia piirteitä. Se, mitä pidämme kauniina, perustuu kuitenkin perinteeseen ja sanattomiin sopimuksiin. Tämä pätee myös elämyksiin ja kehollisiin aistihavaintoihin, joita ohjaavat kulttuuriset käsitykset ja yhteisesti sovittu luonnon kokemisen perintö. (Hallikainen ym., 2014, s. 42-44; Karjalainen, 2007, s. 53, 56-57; von Bonsdorff, 2007, s. 37, 45.) Luonnonympäristössä matkailuelämykseen liittyy kehollisuus, kun ihminen samanaikaisesti ilmaisee itseään fyysisesti ja kytkee toimintansa kulttuurisiin käsityksiin luonnossa liikkumisesta. Tietoisuus luonnossa liikkumisesta syntyy erityisesti silloin, kun luonnossa ollaan virkistyksen takia. (Edensor, 2001, s. 82-84.)

Ympäristöpolitiikan tutkijan Yrjö Hailan (2004, s. 9-10) mukaan retkeily on asettumista luonnon kanssa aktiivisesti tekemisiin, ja retkien kohteena voi olla myös ympäristö, joka on syntynyt aikaisempien sukupolvien työn tuloksena. Hän puhuu niin sanotusta ensimmäisestä ja toisesta luonnosta: jälkimmäinen merkitsee todellisuuksia, joita ihminen rakentaa luonnon sisälle (viljelmät, tiet, vesiväylät) ja jotka mielikuvissa muuttuvat luonnon kaltaisiksi. Toiseen luontoon kuuluvat niin ikään kulttuuriset tekijät, kuten tavat, säännöt ja ylisukupolviset tarinalinjat. (Haila, 2004, s. 189-191.) Kulttuuriperintökeskustelun painopisteen siirryttyä 2010-luvulla aineettoman ja elävään kulttuuriperintöön on ihmisen ja luonnon välinen suhde alettu entistä vahvemmin mieltää osaksi kulttuuriperintöä (Ilmolahti ym., 2018). Eri aloilla on pyritty purkamaan kulttuurin ja luonnon välistä dikotomiaa (Byrne, 2013; Kallinen, Nygren \& Tammisto, 2012), ja tämä on näkynyt myös luontomatkailun tutkimuksessa (Rantala, 2017, s. 61-62). Metsämuseo Lustossa on omaksuttu metsäkulttuurin ja metsäsuhteen käsitteet, joilla tarkoitetaan metsien syvää sidonnaisuutta suomalaiseen kulttuuriin ja historiaan (Lusto, 2015, s. 10). Aineettomaksi kulttuuriperinnöksi ymmärretty metsäsuhde nähdään myös mahdollisuutena maabrändin vahvistamiseen ja matkailun edistämiseen (Karhukorva, Kärkkäinen \& Paaskoski, 2017, s. 23). 
Luonto on suomalaisen matkailupuheen kärki, ja se on tärkeä etenkin syrjäseutujen taloudelle. Itä-Suomessa matkailu on keskittynyt suojelualueiden ympäristöön (Laukkanen, 2010; Saarinen, 2005, s. 120-122). Raja-alueen vihreän vyöhykkeen kulttuuriperinnön katsotaan kytkeytyvän luonnonympäristöön. Seutuja, joilla on tarjolla sekä kulttuuria että suojelualueita, pidetään aluetaloudellisesti tärkeinä. (Ympäristöministeriö, 2014.) Suomen markkinoiminen puhtaan luonnon maana voimistui 1980- ja 1990-lukujen taitteessa, jolloin hiljaisuus ja liikkumatila alettiin ymmärtää koko ajan vähenevinä niukkuushyödykkeinä. Samalla ryhdyttiin vahvistamaan myyttiä suomalaisten mutkattomasta luontosuhteesta. Ympäristötietoisille länsisaksalaisille suunnatussa kampanjassa pyrittiin yhdistämään luontoon liittyvät myönteiset mielikuvat Suomeen painottaen samalla suomalaista luontosuhdetta:

Käsitteestä 'Finnland' pyritään tekemään sellaisen maan ja kansan perikuva, joka hyödyntää luontoaan harkitulla tavalla, saa siitä teknistä ja taiteellista inspiraatiota ja osittain toimeentulonsakin sekä elää sen kanssa luontevassa vuorovaikutuksessa. (Hemming, 1989, s. 6-7)

Lainauksessa kiinnittää huomion verbi "tehdä". Kyse on historiakulttuurisesta prosessista, jossa luonnonläheisyys saadaan kuulostamaan suomalaisen geeniperimän ja kansanluonteen keskeiseltä piirteeltä. Kansallisesta luontosuhteesta puhuttaessa kyse on konstruktiosta. Jokaisen suomalaisen luontosuhde on erilainen riippuen muun muassa työskentely-ympäristöstä sekä elämänkäytännöistä ja -kokemuksesta. Kollektiivisen suomalaisen metsäsuhteen - jonka sekä keskiluokkaiset luonnonsuojelijat että maaseutuväestö voivat käsittää - voidaan ajatella syntyneen vasta 1900-luvun lopun metsäliikkeiden seurauksena. (Haila, 2004, s. 37-39.)

1900-luvun viimeisten vuosikymmenten matkailupuhe heijasteli luonnonsuojelussa ja kulttuuriperinnön kentällä tapahtuneita muutoksia. Euroopassa, etenkin ranskankielisillä alueilla, oli 1970-luvulta lähtien alettu perustaa yhteisöllisiä ekomuseoita, joissa luonnon- ja kulttuuriperintö yhdistyivät paikallisyhteisöstä nousevaan osallisuuteen, ja laineita ajattelusta rantautui Suomeenkin. (Ks. Ilmolahti ym., 2018.) Suomen luonnonsuojeluliitto järjesti vuonna 1980 kansallispuistonäyttelyn, jonka yhdessä infojulisteessa pohdittiin luonnonpuistojen merkitystä kulttuurimuistomerkkeinä. Jos vain osasi etsiä, luonnon keskeltä saattoi löytää "asuinsijoja ja hautoja, eräkulttuurin kaivamia pyyntikuoppia, hakamaita ja kaskikoivikoita, tervahautoja, maatuvia pitkoksia ja ikääntyvien puiden kylkeen veistettyjä pilkkoja” (Työväenmuseo Werstas). Näyttelytaulussa ehdotettiin ekomuseoiden perustamista luonnonsuojelualueille, jolloin historia ja kansanperinne manifestoituisivat elävämpinä kuin kirjoista luettaessa.

Ajatus luonnonpuistoista osana kulttuurihistoriaa ei ollut uusi - koko kansallispuistojen syntyhistoria on vahvasti sivistyksellinen. Kansallispuistot voidaankin nähdä paitsi luonnonsuojelualueina myös museoina, jotka toimivat luontoon liittyvien kulttuuristen määreiden välittäjinä. Pohjoismaisen kansallispuistoajatuksen isänä pidetty A. E. Nordenskiöld käsitti 1880-luvulla kansallispuistot museoina ja elävinä tauluina (mm. Hildén, 1927, s. 57; Kalliola, 1954, s. 18; Palmgren, 1922, s. 52). Myös Rolf Palmgrenin klassikkoteoksessa Luonnonsuojelu ja kulttuuri (1922) aihepiiriä lähestyttiin ihmisen näkökulmasta. Ihmisen alkuperäinen elinympäristö oli häviämässä, ja siitä haluttiin säilöä esimerkkialueita tulevia sukupolvia varten. Palmgren rinnasti luonnonmuistomerkit muistopatsaisiin ja totesi, että ne ovat yhtä arvokkaita historiallisia todisteita kuin muinaistieteelliset löydökset. (Palmgren 1922, s. 17, 21-29, 32-39.) 
Saman sivistyksellisen näkökulman jakoi kasvitieteilijä Kaarlo Linkola, joka oli laatinut eduskunnalle tehdyn esityksen luonnon- ja kansallispuistojen perustamiseksi (Linkola, 1926). Linkola (1927) puhui kansallispuistoista isänmaan luonnon ja saloseutujen tunnelman näytteinä. On huomattava, että myös esimerkiksi metsänhoitajat, jotka työnsä kautta edustivat luonnon hoitajia ja muokkaajia, omaksuivat ennen toista maailmansotaa luonnonsuojelun periaatteet (Perttula, 2006, s. 16-17). Metsänhoitaja Ilmari Hildén kirjoitti vuonna 1927, että nyt oli yhdestoista hetki pelastaa alkuperäisiä, ihmiskäden kosketukselta säästyneitä alueita. Yksittäisten kohteiden rauhoittaminen ei enää riittänyt, vaan oli Yhdysvaltojen ja Ruotsin esimerkin mukaan luotava alueita, ”joissa me ja jälkipolvemme vielä voimme nähdä kuvan isiemme maasta sellaisena, kuin se vuosisatoja sitten oli, jonne voimme elämän kiihkoisasta kiireestä tehdä todellisia pyhiinvaellusmatkoja”. (Hildén, 1927, s. 59.)

Samoja sivistyksellisiä painotuksia oli nähtävissä myös kansallispuistojen toisessa perustamisaallossa toisen maailmansodan jälkeen, vaikka luonnonsuojelussa tapahtuikin aatteellista muutosta ja eriytymistä (Perttula, 2006, s. 20). Kansatieteilijä Kustaa Vilkuna korosti kansallispuistoja esimerkkeinä neitseellisestä metsäryteiköstä, johon karjalaiset ja savolaiset kaskitalonpojat olivat aikanaan tunkeutuneet. Luonnonpuistojen tuli olla museolaitoksen kivijalka, jolle kulttuurin ymmärrys rakentui. (Vilkuna, 1950, s. 13.) Kasvitieteilijä Reino Kalliola määritteli luonnonsuojelutyön vanhimmaksi osaksi "kulttuuri-luonnonsuojelun": luonnon säilyttämisen ja hoitamisen tieteellisistä, opetuksellisista, historiallisista, esteettisistä ja eettisistä syistä (Kalliola, 1953, s. 6). Ihmisen lähtökohdista nouseva näkökulma korostui etenkin kansallispuistoissa, jotka on tarkoitettu alkuperäisen luonnon näytteiksi sivistyksellisessä mielessä, kun taas suljetut luonnonpuistot säilyttävät tieteellistä aineistoa ensi sijassa tutkimusta varten (Söyrinki, 1957, s. 4).

Edellä kuvatut näkemykset kansallispuistoista muistuttavat sosiologi Ulrich Beckin (1990, s. 64) esittämää ajatusta suojellusta luonnosta luontomuseoina tai sivilisaatioarkkeina häviämässä oleville lajeille. Beckin noin sata vuotta Nordenskiöldin aloitteen jälkeen julkaisemassa pamfletissa pelot luonnon katoamisesta näyttävät tulleen toteen, ja luonto on muuttunut keinotekoiseksi toiveluonnoksi. Museoitua, osittain jo utopiaksi muuttunutta luontoa myydään ihmisille, jotka kaipaavat luonnon mahdollistamaa verkkaisuuden kokemusta. Ekologisen havahtumisen kaikupohjana toimii luontoa koskevan kulttuurisen hahmotelman vaarantuminen, ei luonnon tuhoutuminen sinänsä (Beck, 1990, s. 62-64, 84-86).

Kansallispuistoihin 1900-luvulla liittyvän kirjoittelun perusteella voidaan päätellä, että luonnonsuojelualueita on perustettu pitkälti ihmislajin historian säilömiseksi. Merkitysanalyysin kriteereistä autenttisuus on yksi tärkeimmistä määreistä kansallispuistojen merkityksiä tarkasteltaessa. Kansallispuistot tarkoitettiin näytteiksi esi-isien elinympäristöstä. $\mathrm{Ne}$ ovat "pysäytettyjä" in situ -museoita (Pihlman, 2007, s. 210), mutta samalla niiden luonto on jatkuvassa muutoksessa. Suojelualueiden arvon nousu on suoraan verrannollinen luonnontilaisten alueiden harvinaistumiseen, ja luontomatkailun suosio kasvaa, kun pelko luonnon menettämisestä lisääntyy (Petrisalo, 2001, s. 38-38). Koko Fennoskandian vihreä vyöhyke voidaan nähdä uhanalaista boreaalista metsäluontoa esittelevänä luontomuseona. Aluetta on kutsuttu "Euroopan viimeiseksi erämaaksi" (Laukkanen, 2010, s. 7), mikä korostaa alueen poikkeuksellisuutta ja luonnon asemaa niukkenevana hyödykkeenä. 


\section{Pohjoiskarjalaisten luontokohteiden kulttuuriset ja kokemukselliset merkitykset}

Luontomatkailija hakee pääsääntöisesti kauniita maisemia, hiljaisuutta, rauhaa ja luontokokemuksia (Tyrväinen \& Tuulentie, 2017, s. 8). Tämä ei kuitenkaan sulje pois kiinnostusta kulttuuriin tai historiaan. Luonnossa vaeltaja saattaa etsiä syvääkin yhteyttä menneisyyteen pyhistä luonnonpaikoista, vanhan asutuksen liepeiltä, saalismailta tai kaskeamisen muovaamista näkymistä. On arveltu, että luontoon jääneet merkit ihmisen toimista lisäävät luonnonpaikan elvyttävyyttä. Tietoisuus kulttuuriperinnöstä korostaa yhteenkuuluvuutta paikan kanssa ja lisää kokemukseen inhimillisen ulottuvuuden: tavatessaan ihmisen jättämän jäljen kulkija kokee kuuluvansa sukupolvien jatkumoon ja aistivansa menneisyyden läsnäolon. (Leppänen \& Pajunen, 2017, s. 72-75.)

Paikallinen luontomatkailuyrittäjä kuvaili Retkipaikka-sivustolla vuoden 2019 alussa Pohjois-Karjalaa idän kätketyksi helmeksi, jonka olemassaoloon matkailumarkkinat ovat vasta alkaneet herätä. Tekstissä tuotiin esille luonnon ja historiakulttuurin yhteys:

Retkeily tykkylumen peittämässä metsässä on matka toiseen aikaan ja paikkaan. Itä-Suomen pitkät, jo lähes unohdetut vaellusreitit kulkevat rajavyöhykettä myötäillen läpi vanhojen, sodanaikaisten linnoitteiden. Ne muistuttavat kulkijaa ihmisen ja sodan mielettömyydestä, mutta myös suomalaisten omasta lähihistoriasta. (Kettunen, 2019)

Tekstin kirjoittaja hyödyntää kulttuurista luontoa myös yrityksensä tarjonnassa: puhtaan ilman ja hiljaisuuden lisäksi retkillä on mahdollista kokea, miten ihminen on aikoinaan ollut osa luontoa ja elänyt luonnon rytmissä. Esimerkiksi Kolille suuntautuvat vaellukset painottuvat kahteen mielikuvaan: taiteilijoiden Koliin sekä paikkaan liittyvään kansanuskoon. Pakanamaa-kierroksella kerrotaan suomalaisesta mytologiasta ja Kolista pyhänä paikkana, jossa asui noitia vielä 1900-luvulla. (Karu survival.)

Kohteiden merkitseminen tai merkitsemättä jättäminen ovat valintoja, jotka kertovat menneisyydelle matkailussa annetuista merkityksistä. Maantieteilijä Petri Raivon (2007, s. 277-279) mukaan paikkoihin liittyviä merkityksiä on ylläpidettävä; historialliset kohteet muuttuvat muistin paikoiksi vasta tarinoiden ja merkitsemisen avulla. Opastaulu tai muistomerkki tekee paikasta erityisen. Esimerkkinä Raivo mainitsee Ilomantsissa sijaitsevan Taistelijan taipaleen, historiapolun, joka kertoo erään hyökkäyksen vaiheet. Tekstit ovat taisteluun osallistuneiden suunnittelemia. Paikka ei sinänsä eroa ympäröivästä luonnosta, mutta henkilökohtainen taso tekee siitä kävijälle autenttisen. (Raivo, 2007, s. 278-279.)

Kasvuston alle ja joukkoon on piloutuneena runsaasti ihmisen ja luonnon vuorovaikutukseen liittyvää ainesta. Metsähallitus suoritti vuosina 2010-2015 inventoinnin valtion metsiin kätkeytyvästä kulttuuriperinnöstä. Kartoituksessa löydettiin esimerkiksi satoja ennestään tuntemattomia kivikautisia asuinpaikkoja, joista vanhin sijoittui Ilomantsiin Muinais-Koitereen rannoille. (Taivainen, 2016, s. 29-32.) Inventoinnin tuloksia on hyödynnetty muun muassa maasto-opasteissa ja luontokeskuksissa (Metsähallitus).

Lieksan ja Ilomantsin kuntien alueella sijaitsevat kolme kansallispuistoa yhdessä Kesonsuon ja Ruunaan luonnonsuojelualuiden sekä Koitajoen Natura-alueen kanssa tarjoavat matkailijoille runsaasti avointa luonnontilaista ympäristöä. Myös suojeltu ympäristö on kyllästetty vihjeillä 
ihmisen menneisyydestä. Esimerkiksi Koitajoen alue on niitä täynnä sodan merkeistä ja metsänvartijatorpista elinkeinojen (kaskeaminen, turvetuotanto, hakkuu, uitto) jättämiin jälkiin. Koitajoen aluetta esitettiin vuonna 1993 kansallispuistoksi, mutta hanke kariutui paikallisten vastustettua metsästyksen rajoittamista. (Similä, Tervonen \& Tuhkalainen, 2006, s. 33-37.) Luontomatkailusta ja etenkin koskenlaskusta tunnetulla Ruunaan luonnonsuojelu- ja retkeilyalueella kulttuuriperintö linkittyy veteen ja itärajaan: historiakuvan keskeisiksi piirteiksi on nostettu uitto- ja rajankäynnin perinne sekä asutushistoria. (Laukkanen, 2010, s. 12-13.) Ruunaan alueella tehtiin vuonna 2010 kulttuuriperintökartoitus, jossa löydettiin 45 uutta kulttuuriperintökohdetta. Näistä noin puolet oli muinaismuistolainsäädännön mukaisesti suojeltavia. Tutkimus osoitti, että alueella oli oleskeltu jo kivikaudella, ja Lieksanjoen reitti oli ollut merkittävä kulkutie jo tuolloin. Kartoituksessa esitettiin esimerkiksi kivikautisten asuinpaikkojen yhteydessä olevaa suurta hiilimiilukeskittymää opastuskohteeksi. (Taivainen, 2010, s. 10-11.)
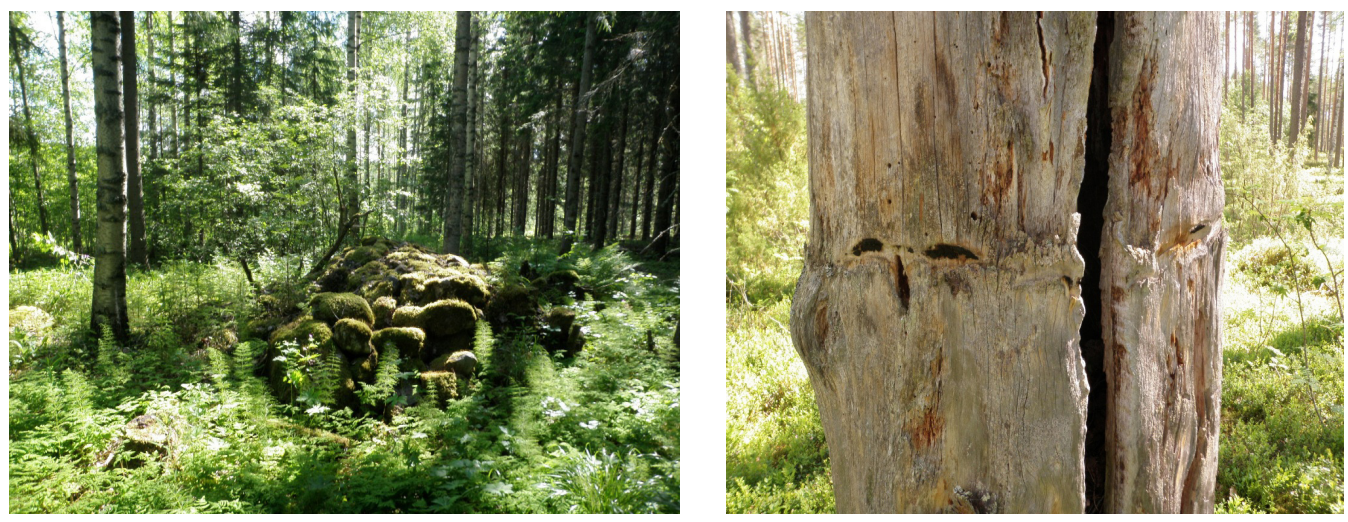

Kuva 3. Lieksassa sijaitsevan Ruunaan alueen kulttuuriperintökartoituksessa löytyi vuonna 2010 useita muinaismuistokohteita. Samalla paikallistettiin muita ihmisen luonnonympäristöön jättämiä jälkiä, kuten maatilojen jäänteitä (vasemmalla) ja kaskeamisesta kertovia pykälikköpuita. (Kuvat: Jouni Taivainen / Lusto / Metsähallituksen metsätalouden kulttuuriperintöinventointikokoelma.)

Pohjois-Karjalan biosfäärialueelle sijoittuvilla kansallispuistoilla on jokaisella selkeä kulttuurihistoriallinen profiilinsa. Vanhin on Petkeljärven vuonna 1956 perustettu, jo aiemmin hoitoalueena toiminut kansallispuisto. Sen perustaminen sijoittuu aikaan, jolloin tavoitteena oli korvata alueluovutuksissa menetettyjä suojelualueita. Alueen sopivuutta kansallispuistoksi perusteltiin vuonna 1948 sekä esteettisin, luonnontieteellisin että kulttuurisin määrein: kaunis alue harju-, saari- ja järvialueineen edusti Raja-Karjalan karua erämaaluontoa ja kätki kaivantoihinsa muistoja sotavuosilta. Lisäarvona pidettiin karjalaista saloluonnetta edustavaa nimistöä. (Suunnitelma uusiksi luonnon- ja kansallispuistoiksi, 1948, s. 21-22.) Kansallisessa mittakaavassa Petkeljärvi nähtiin ennen kaikkea kalevalaisen saloluonnon edustajana (Björn 2012, s. 62).

Petkeljärven maastossa on nähtävissä myös esihistoriallisen ajan jäänteitä (Kumpulainen, Laiho \& Pirinen, 2007, s. 35), mutta mäkilinnat ja kivikautiset asuinpaikat ovat mielikuvissa ja puiston profiloinnissa jääneet sotahistorian jalkoihin (profiloinnista: Tuhkalainen, 12.9.2017). 
Puiston alueella ei varsinaisesti taisteltu, mutta sotahistoria on kirjottu syvälle sen maaperään: alueella on korsuja, hevossuojia, 72 poteroa ja seitsemän kilometriä juoksuhautoja (Karvinen, 2018, s. 105-107; Kumpulainen ym., 2007, s. 35). Sotahistoria leimaa vahvasti paikalla retkeilevien menneisyyskuvaa (Kansallispuistokeruu, s. 63, 104, 106, 297, 311, 363). Petkeljärveä esitettiin kansallispuistoksi pian sodan päättymisen jälkeen, ja matkailijoilla on vuosikymmenten ajan ollut henkilökohtainen kosketus sotaan; juoksuhautojen äärellä on kuultu monia sotatarinoita (Kansallispuistokeruu, s. 106). Kansallispuistokeräyksessä kerrotaan puistossa vierailleesta miehestä, joka halusi käydä vuosittain paikalla, jossa oli aikanaan saanut tiedon sodan päättymisestä (Kansallispuistokeruu, s. 311).

Patvinsuon vuonna 1982 perustetun kansallispuiston luonto peilautuu alueen asutushistoriaan sekä toisen maailmansodan aikaisiin partisaanitarinoihin ja miilunpolttoon. Vaikka puisto on luonteeltaan erämainen, ihmisen historia on voimakkaasti läsnä. Alueella on muun muassa karsikkopuita, joissa on nähtävissä vuosisatojen aikana tehtyjä merkintöjä. (Karvinen, 2018, s. 109-110; Luontoon.fi.) Kertomus puiston luontotuvan emännän, metsänvartijasuvun jälkeläisen, tarinoinnista nuotiolla yhdistää luontokokemuksen paikalliseen muistelukerrontaan, mikä lisää elämyksen merkityksellisyyttä:

Makkarat paistettiin Virtaniemen leiripaikalla, joka on muinainen asuinpaikka. Sieltä on löydetty kivikautista esineistöä. - - Tulta tuijotellen juttelimme pimeässä syysillassa--. Suomun emäntä -- kertoo tarinoita partisaaneista, karhun kohtaamisista ja Suomunjärven tukinuitosta. Viimeiset tukit on uitettu Suomulta Koitereeseen vuonna 1962. Keskellä kansallispuistoa sijaitseva Iso-Maksimainsaari on ollut partisaanien päätukikohta. (Karvinen, 2018, s. 111-112)

Puistoista nuorin, vuonna 1991 perustettu Koli, kuuluu suomalaisen nationalismin ydintarinoihin. Kävijä tuntee usein alueen kulttuurihistoriallisen taustatarinan, ja karelianistinen lataus vaikuttaa luontokokemukseen (Laurén, 2015). Kansallispuistokertomuksissa nousee kuitenkin esille myös paikan asutushistoriaan ja geologiseen menneisyyteen sitoutuva menneisyyskokemus, joka ainakin osin sivuuttaa tietoisen yhteyden kareliaaniseen perinteeseen. Kansallispuisto koetaan riittävän autenttiseksi simuloimaan menneiden sukupolvien luontokokemusta (Kansallispuistokeruu, s. 393; Laurén, 2015, s. 8). Paikan tuntu liitetään Karelidien vuoristoon. Eräs matkailija kuvailee Kolin haikean tuulen itkevän ikävöidessään muinaisia vuoria, joiden lomassa se aikanaan sai puhaltaa (Kansallispuistokeruu, s. 82). Paikallinen oppaanakin toimiva Ilmari Martikainen korostaa geologista menneisyyttä Kolin kaikkein ainutlaatuisimpana suojelukohteena, mutta merkittävimmäksi arvoksi hän nostaa paikan henkisen koskettavuuden (Karvinen, 2018, s. 100.)

Kolin kansallispuiston johtajana toimineen Lasse Lovénin mukaan vain pieni osa matkailijoista hakeutuu kohteeseen kulttuurihistorian johdattamana, mutta luontomatkailijat olisi mahdollista saada kiinnostumaan myös siitä, miten ihmisen kulttuuri on aikojen saatossa nivoutunut luonnonympäristöön. Jo Mustarinnaksi kutsutun vaaran nimeen liittyy kulttuurinen lataus. (Laukkanen, 2010, s. 14; Lovén, 27.6.2017.) Mustarinta-myyttiä onkin hyödynnetty muun muassa kansallispuiston ja luontokeskuksen markkinoinnissa (Koju Film Company, 2014). Myös retkeilijät näyttävät omaksuneen tarinan: 
Jo pelkkä Kolin nimi, kun sitä matkan lähestyessä maisteli, herätti syvän kunnioituksen. - - Samalla mieleen kohisi jostain muistin pölyisistä sopukoista sana Mustarinta. Se on paitsi toinen nimitys karhulle--myös nimi, jota Kolista käytettiin vielä ainakin 1700 luvulla -- . Jylhää Kolia pidettiin pyhänä alueena, jolla kerrotaan asuneen mahtavia henkiä. (Huttunen, 2014)

Menneisyyteen liittyvät tarinat nivoutuvat luonnossa liikkumiseen. Matkailijan luonnossa havainnoima menneisyys hahmottuu erään retkeilijän kertomuksessa: hän näki painajaisia yöpyessään paikalla, jossa sijaitsi venäläisten sotakarkurien hauta. Retkeilijän kulkema Pohjois-Karjalan vaellusreitti oli täynnä sotahistorian muistin paikkoja: tuhottu panssarivaunu, räjäytetty silta piikkilankoineen, poteroita, panssarintorjuntakiviä, Rukajärven tie. (Kansallispuistokeruu, s. 107-109.) Toinen kertoja puolestaan puhuu kalliomaalauksista, kohtaamastaan rajakivestä ja Lieksassa Surkansuolla näkemistään opaskylteistä, joissa kerrottiin tavasta karkottaa karhu emännän pyllistyksellä (Kansallispuistokeruu, s. 42-47).

Konkreettisten ihmisen jättämien jälkien lisäksi myös luonnon personointi liittyy menneisyyskuvan hahmottamiseen: tykkypuut näyttävät eläviltä hahmoilta ja liekkien varjot luovat mielikuvan tulen ympärillä tanssivista olennoista (Kansallispuistokeruu, s. 347, 387; Karvinen, 2018, s. 101). Luonnonpaikkoihin liittyvässä kokemuskerronnassa puhutaan joskus ajantajun hämärtymisestä tai pyhyyden ja iäisyyden kokemuksista (Kansallispuistokeruu, s. 113, 144). Tätä voi kutsua luontoon sulautumiseksi, mutta fenomenologisesta näkökulmasta kyse on ruumiin tuottamista havainnoista; epätosi muuttuu kokijalle todeksi (Hotanen, 2010, s. 140). Nämä kokemukset voimistuvat, jos paikkaan on jo valmiiksi latautunut kulttuurihistoriallisia tarinoita.

Myös luonnonympäristön hoitaminen vanhoin menetelmin kiinnostaa matkailijoita. Kansallismaiseman lisäksi Kolin kansallispuiston matkailijoita viehättävät perinnetilat, kaskitalouden vaikutuksesta muodostuneet ahot ja niityt sekä tiloilla laiduntavat lampaat ja kyytöt (Karvinen, 2018, s. 100; Tuhkalainen 23.9.2017). Etenkin kaskiviljely on kulttuurisesti tärkeä ihmisen ja luonnon suhdetta Itä-Suomessa määrittänyt tekijä. Sillä on merkitystä paitsi luonnon ennallistamisessa ja sitä kautta luontomuseon ylläpitämisessä, myös identiteetin vahvistajana. Suunnitelmallinen kaskeaminen aloitettiin Kolilla vuonna 1994, ja neljä vuotta myöhemmin avattiin ensimmäinen teemaluontopolku "Kasken kierros". Kaskikulttuuri ja sen vaikutus vaara-Karjalan luonnonympäristöön on Kolilla nähty tärkeänä luonnonperintönä, jota halutaan ylläpitää. (Martikainen, Kullberg \& Lovén, 2006.) Kaskeaminen edesauttaa myös biodiversiteetin säilyttämistä, joka sekin on oleellinen osa kulttuurista luontomuseota (Martikainen ym., 2006, s. 20).

Kasken kierrosta kulkevat voivat paitsi ihailla luonnonympäristöä myös poimia syksyisin kaskipelloilla kasvavaa naurista (Martikainen ym., 2006, s. 6, 27). Lähiseudun majoituspaikan vetonaulana toimivat Kolin kaskirukiilla täytetyt olkipatjat (Kuikka, 7.1.2019). Kaskeamista, samoin kuin vaikkapa luhtaniittyjen hoitamista Petkeljärvellä, voisi hyödyntää matkailussa myös elämyksellisemmin. Kaskeamisesta on tullut tärkeä talkootyön muoto, ja kaskeamiseen voi periaatteessa osallistua kuka tahansa (Martikainen ym., 2006, 36), mutta sitä ei yleisemmin mainosteta. Esimerkiksi Metsähallituksen paimenviikkojen suuri suosio viittaa siihen, että ihmisiä kiinnostaa osallistuminen elämykselliseen toimintaan. Eläytyminen menneisyyden ihmisen luontosuhteeseen on merkityksiä tuottavaa: 
Kesällä 2012 pääsin kokemaan kansallispuistossa Ollilan tilalla karjankutsuhuudot. - - Oli vaikuttavaa nähdä kyyttöjen käynti, juoksu, tempoilu ja huutoon rauhoittuminen, kun ne vaihtoivat laidunta toiselle. Karjankutsujan ääni ja runonlaulun melodiat jäivät mieleen. (Kansallispuistokeruu, s. 55-56)

Sopivasti taustoitettuina osallistava toiminta voisi yhdistää paikallisen historiakulttuurin ja ympäristönhoidon ja tavoittaa tällä tavoin sekä historiasta että luonnosta kiinnostuneita matkailijoita. Se, mikä vielä hetki sitten oli jokapäiväistä elämää, on nyt elämyksellistä yhteyttä menneisyyteen.
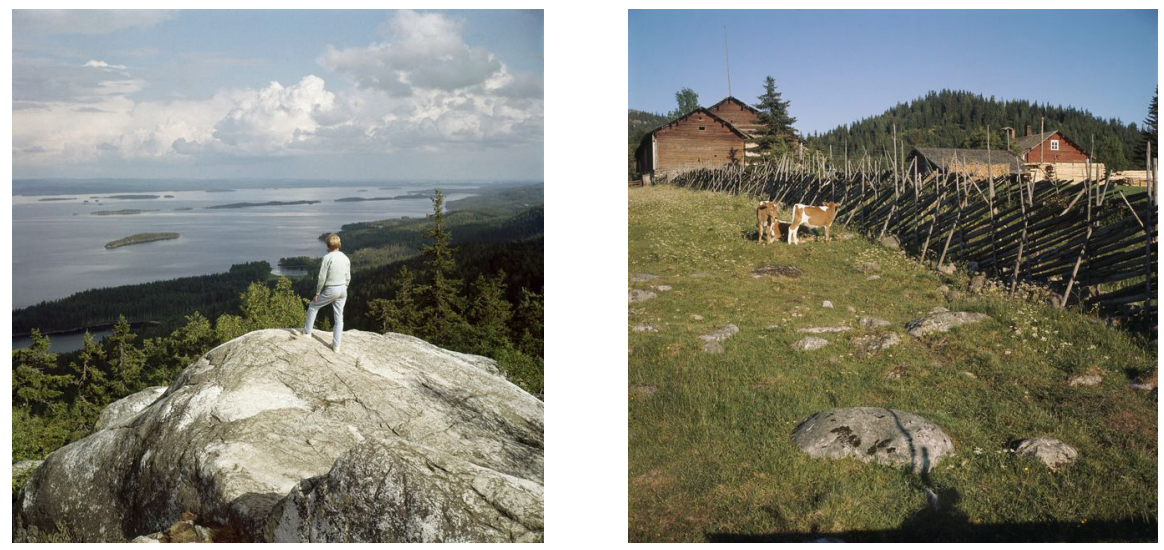

Kuva 4. Kaksi Kolia: kansallismaisema ja esi-isien elinympäristö. (Kuvat: Volker von Bonin / Historian kuvakokoelma / Museovirasto.)

Museonjohtaja Johanna Lehto-Vahtera on pohtinut kotimuseota merkitysanalyysin näkökulmasta todeten, että "autenttisuus pyrkii pakenemaan kodin muuttuessa museoksi". Tästä huolimatta kävijät tavoittavat paikan elämyksellisyyden paitsi tuoksujen ja interiöörin etenkin kokoelmien, esineiden, asiakirjojen ja tallenteiden välittäminä (Lehto-Vahtera, 2014, s. 40-41). Sama ajatus pätee kansallispuistoihin: tieto syventää niistä saatuja kokemuksia. Täydellistä rekonstruktiota menneisyyden luonnonoloista ei voida luoda, mutta mitä enemmän aikaisemmille sukupolville tärkeistä paikoista on saatavissa tietoa, sitä paremmin on mahdollista samastua luonnon fyysisen kokemisen ohella myös entisajan ihmisen luontosuhteeseen. Tämä tuo lisäarvoa kansallispuistoihin matkailukohteina. Ne eivät ole vain retkeilypaikkoja vaan tiloja, joissa ihmisen ja biosfäärin välisen vuorovaikutuksen voi kokea monitahoisesti kulttuurihistoriallisen tiedon täydentäessä fyysistä kokemusta.

Aineistosta voidaan vetää se johtopäätös, että luontokohteiden käytettävyysarvo ja elämyksellisyys lisääntyvät, kun kävijällä on tietoa paikan menneisyydestä. Kun kulkija sata vuotta sitten kaipasi Kolille kunnollista opastusta ja infrastruktuuria (Hämeen-Anttila, 1922), on nykymatkailijalla jo valittavanaan useita monipuolisia reittejä. Kohteisiin voisi tuoda lisäarvoa kartta tai sovellus, joka avaisi kävijälle maaston asutus- ja kulttuurihistoriaa sekä paikallisia tarinoita. 


\section{Runokarjalaa matkailijoille - kansallisen katseen lävistämä historiakuva}

Pohjois-Karjalan maakuntaliiton toimesta vuonna 2014 laaditussa toimenpideohjelmassa nostettiin esille niin hyvinvointi-, luonto- kuin kulttuurimatkailukin. Myös hyvinvointimatkailu kytkettiin pitkälti luonnon avulla saavutettaviin terveyshyötyihin. Tyypillisiksi kulttuurimatkailijoiksi identifioitiin modernit humanistit, joita kiinnostavat historia, elämäntavat, ruokakulttuuri ja aidot kokemukset. Ohjelmassa todettiin luontoretkeilykohteisiin suuntautuneiden matkailijamäärien olevan kasvussa. Luonto- ja kulttuurimatkailun kehittäminen nähtiin pääosin erillisinä, ja luontomatkailu sai suunnitelmissa hallitsevan aseman kulttuurimatkailun keskittyessä perinteisiin teemoihin: karjalaisuus, Kolin karelianismi, sotahistoria, ruokakulttuuri ja käsityöperinteet. (Pohjois-Karjalan maakuntaliitto, 2014.)

Ilomantsi on 2000-2010-lukujen matkailuviestinnässä esitetty romanttisena rajaseutuna, joka on syrjässä elämän kiireisyydestä (Björn, 2012, s. 61). Kunnan kotisivulla pitäjä esitellään sotahistorian näyttämönä, Kalevala-kuntana, Suomen ortodoksisimpana paikkakuntana sekä erämaisen luonnon alueena ja karjalaisen kulttuurin vaalijana (Ilomantsi). Ilomantsissa on omaksuttu termi rajakarjalaisuus, jota käytetään viitattaessa alueen luontoon ja historiaan. Kuten karjalaisuuden määritelmät yleensäkin, rajakarjalaisuuden käsite on enemmän symbolinen kuin maantieteellinen. Virallisesti termiä Raja-Karjala on käytetty Suomeen ennen toista maailmansotaa kuluneesta Salmin kihlakunnasta (Wartiainen, 1927, s. 168). Myös Ilomantsi ja tämän tytärkunta Tuupovaara saatettiin joissain tapauksissa lukea Raja-Karjalaan kuuluviksi (Brander, 1927, s. 62-63).

Karjalaisen kulttuurin esittämiseen vakiintuneiden määreiden mukaisesti on historialliset syynsä. Matkailualueena Pohjois-Karjala oli ennen toista maailmansotaa - Kolia ja Pamilonkoskea lukuun ottamatta (Hultin, 1927; Sulopuisto, 2018, s. 8-21) - Karjalan kannaksen ja Laatokan Karjalan varjossa. Laatokan Karjala oli periferiaa, missä luonnon läheisyys ja siihen liittyvä tapakulttuuri toivat matkailuun eksoottisen vivahteen:

"Runojen ja metsäin Karjalaa" on Rajakarjala. Siellä laulujoutsen vielä lepää rämeestä lähteneen joen ruskealla vedenpinnalla, siellä hirvet ja peurat kätkeytyivät tiheikköihin, siellä kuhisee järvissä tummia haukia ja kirkkaissa harjujärvissä heleänpunaisia ahvenia. Siellä on vielä jäljellä paljon karjalaista tunnelmaa - luonnon salaperäisyyttä, joka saa kulkijan - - laskeutumaan polvilleen ja painamaan päänsä maata kohti luomakunnassa ilmenevän--salaperäisen ja kaunïn edessä. (Rosberg, 1927, s. 17)

Eksoottisuus liittyi etäisyyteen: matkailijan vaivautuessa syrjäseudulle hänen uskottiin haluavan nähdä omaperäistä kansaa ja luontoa, Kalevalan taikamaita (Wartiainen, 1927, s. 168-169). Seutuun kehotettiin tutustumaan mitä pikimmin: Raja-Karjala oli ollut vaikeakulkuisten taipaleitten takana, mutta uusien yhteyksien vuoksi sen kansatieteellinen alkuperäisyys alkoi olla vaarassa (Brander, 1927, s. 75). Syrjäseuturomantiikalla kuvailtiin myös Pohjois-Karjalaa. Viipurin ruotsalaisen lyseon lehtori Herman Hultin oli Pamilonkoskella vieraillessaan löytänyt etsimänsä erämaaympäristön, mutta itse koski oli kadonnut: sitä peitti 50000 tukin muodostama tukos, jonka alla koski raivoissaan pauhasi (Hultin, 1927, s. 190-191, 196-197). Hultinin kirjoitus kuvaa ihmisen ja luonnon toimijuuden välistä konfliktia aikana, jolloin metsäteollisuus ja 
luonnon laajamittainen hyödyntäminen tukkilaistarinoineen oli peittämässä alleen kansallisromanttista erämaataulua.

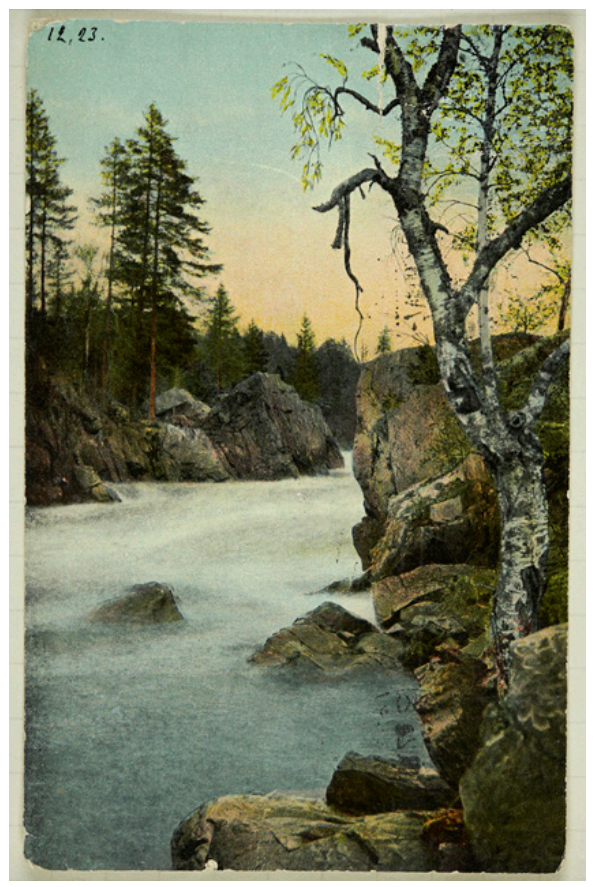

Kuva 5. Erämaan mystiikkaa. Koitajoen Pamilonkoski kuvattuna 1900-luvun alkuvuosien postikorttiin. (Kuva: Karjalaisen osakunnan kokoelma / Museovirasto.)

Toisen maailmansodan jälkeen laatokankarjalaisen perinteen säilyttäminen siirtyi Pohjois-Karjalalle, ja osan alueestaan menettäneestä Ilomantsista tuli itäisemmän alueen perinteen kantaja. Tuupovaaralle jäi aluemenetysten jälkeen palanen Korpiselän pitäjää, jonka historiakulttuuria oli pitkään rakennettu erämaaluonnon varaan. Toisen maailmansodan jälkeisessä kotiseutuliikkeessä perustettiin yhdistyksiä ja museoita säilyttämään katoavaa maailmaa ja rakentamaan kulttuurista identiteettiä. Samalla maaseudun tyhjentyville alueille etsittiin uusia elinkeinoja. Itärajan kunnat perustivat vuonna 1965 maamme ensimmäisen matkailutien, Runon ja rajan tien (Sulopuisto, 2018, s. 28). Tämä kertoo tarpeesta käsitteellistää uutta itärajaa ja hyödyntää menetettyihin alueisiin liitettyjä mielikuvia osana uuden rajaseudun matkailua. 1980-luvulla Ilomantsi-Tuupovaaran aluetta alettiin tietoisesti markkinoida Runo-Karjalan nimellä (Piitulainen, 2014).

Runo-Karjalan ydin, Kalevala, on paitsi yksi alueen historiakulttuurin avaintarinoista myös tekijä, joka sitoo yhteen historiakulttuurin ja luontosuhteen (Aineeton kulttuuriperintö). Ilomantsi julistautui vuonna 1982 Kalevala-kunnaksi, jolla oli oikeus kantaa kansalliseepoksen perinnettä, koska Kantelettaren keskeisiä runoja on kerätty kunnan alueelta. Taustalla oli kilpailu siitä, kuka on oikeutettu käyttämään eeposta matkailullisena houkuttimena. (Martikainen, 
2011, s. 4, 47, 54.) Kalevalainen perintö näkyy etenkin Parppeinvaaran runokylässä, jonne on siirretty Lönnrotille laulaneen Mateli Kuivalattaren aittoja (Parppeinvaaran runokylä).

Myös Kalevalaa voidaan tarkastella historiakulttuurin näkökulmasta. Kalevalaiseksi menneisyydeksi mielletty tarina oli Lönnrotin valintoihin perustuva konstruktio, jossa luonnontilainen syrjäseutu näyttelee keskeistä osaa. Lönnrot karsi pois esimerkiksi Ilomantsin alueelta kerättyä seksuaalista runoutta, ja Mateli Kuivalattarelle Kantelettaren esipuheessa suotu merkintä nosti tämän ikoniseksi hahmoksi, vaikka Kuivalattaren roolista ei kaikilta osin olekaan varmaa tietoa. 1900-luvun alussa Kuivalattaresta alkoi tulla koko pitäjän runomaineen ylläpitäjä. Runonlaulajakuvien muotoutumisessa ei ole kysymys tarkoitushakuisesta keksimisestä, mutta valikoiminen on tehnyt menneisyydestä kunkin ajan tarpeisiin muokkautuvaa. (Seppä 2015, s. 12, 68-117).

Historiantutkija Ismo Björn (2012, s. 60) on kutsunut Ilomantsia mielentilaksi, konstruktioksi ja metaforaksi itäsuomalaisuudelle. Turistien on oletettu haluavan nähdä taistelupaikkoja, ortodoksisuutta ja rajaseutua, ja näitä on painotettu esimerkiksi luterilaiseksi koetun savottaperinteen sijaan. Eksoottinen Ilomantsi on monille paikallisille vaikea samastumisen kohde, mutta suurta kertomusta ylläpidetään yhteisestä velvollisuudentunnosta. (Björn 2012, s. 62.) Sama ilmiö näkyy Lieksassa. Kunnan verkkosivuilla historia on typistetty tekstiin, jossa tietokirjailija Asko Saarelainen tiivistää alueen menneisyyskäsityksen. Tarina alkaa paikallisen kirjailijan Heikki Turusen säkeillä, joissa korostuvat Pielinen, vaarat ja havumetsä. Saarelaisen mukaan Lieksassa ovat vuosisatojen aikana kohdanneet itä ja länsi sekä luonto ja kulttuuri, metsä on tarjonnut leivän ja virkistyksen ja kulttuuri ja tavarat ovat liikkuneet Lieksanjokea pitkin. Matkailuun liittyen tuodaan esille karelianismi, Koli ja sotahistoria. (Lieksan kaupunki.) Tekstistä heijastuu tietty ristiriita paikallisen Lieksan ja matkailu-Lieksan välillä: jälkimmäinen on vahvasti kiinni kansallisen katseen varaan rakentuneessa ydintarinassa.

Paikalliskuvauksissa Lieksan menneisyys on yhtä kuin erämaa, vaarat, Koli, Ruunaa ja Pielinen, ja menneisyyskokemus hahmottuu luonnonympäristön välityksellä. Paikallinen kirjailija Heikki Turunen on keskeinen pohjoiskarjalaisen kansanomaisen menneisyyskuvan rakentaja. Teoksessaan Hämärähetken tarinoita (2010) hän on havainnoinut suulliseen perinteeseen pohjautunutta lapsuutensa maailmaa ja reflektoinut ikäpolvensa suhdetta menneisiin sukupolviin: suullisen tarinankerronnan vähentymisen takia yksi menneisyyskuvan tuottamisen linkki tuntuu katkenneen. Turusen teksteissä ilmenee personoitu luonto: metsä, äiti-Pielinen ja Koli, Mustarintainen, Karelidien poika. Turunen kirjoittaa, kuinka Kolin puiden on kuultu soittavan hätäkelloja suomalaisen alkukansan rippeille toivoen, etteivät nämä luopuisi isiensä, Kolin jumalien palvojien uskosta. (Turunen \& Turunen, 1997, s. 119.) Tämän uskon voi mieltää kulttuuriseksi, sukupolvien ketjussa kulkevaksi luontosuhteeksi. Turunen on myös sanoittanut syrjäisyyteen liittyvää alemmuudentunnetta kehottaen arvostamaan luonnosta eläneiden tarinankertojien perinnettä:

Meiltä tulette, hävetkää sitä ja kieltäkää se vaikka kuinka. Olette itää enemmän kuin länttä, - - kertojanasennossa könöttäneiden ahavoituneiden ukonvänttyröiden penskoja, kirjatonta vilkkusilmäistä kototekoisten tarinoiden kansaa. Kalevalan heimoa, järvenselkien vilkettä, heinäniittyjen ja saunansavun ja venetervan tuoksua, harmaita latoja, havumetsän huminaa riihen takana. (Turunen, 2010, s. 34) 


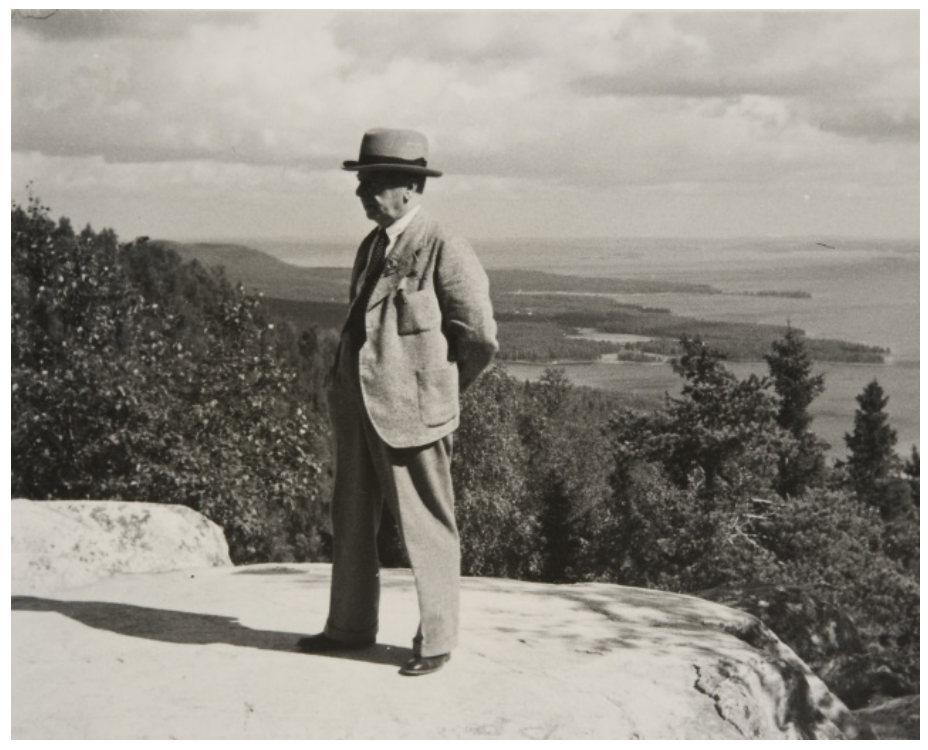

Kuva 6. Pohjoiskarjalaisen maiseman ikonisoinut kuvataitelija Eero Järnefelt Kolilla vuonna 1936. (Kuva: Matkailun edistämiskeskuksen kokoelma / Museovirasto.)

Tämä luonnon rytmissä elävien tarinankertojien paikallisuus ei juurikaan näy alueen markkinoinnissa, vaan matkailijoita varten konstruoidussa historiakulttuurissa Lieksa on useimmiten ulkopuolisen katseen kohde. Pohjois-Karjalan Matkailuyhdistyksen täytettyä 125 vuotta yhdistys valitsi juhlavuoden teemaksi karelianismin uuden tulemisen (Sulopuisto, 2018, s. 58). Alueella virinnyttä uuskarelianismia edustaa vuonna 2015 perustettu Monola-seura, joka on keskittynyt ylläpitämään "Sibeliuksen, Kalevalan ja karelianismin perintöä Pielisen-Karjalan alueella”. Sen ensimmäinen hanke on ollut Johan ja Aino Sibeliuksen häämatkakohteen, Monolan aitan, kunnostaminen ja hyödyntäminen alueen kulttuurimatkailussa. Elämyksellisyyttä on pyritty lisäämään kuljettamalla turistit Lieksan kirkolta koskiveneillä samaa reittiä kuin Sibeliuksen pariskunnan kerrotaan kulkeneen. (Monola-seura.) Karelianismin ja kansanuskon välistä suhdetta ilmentää Ukko-Kolin ystävät -niminen yhdistys, jonka ajattelussa aineettomaksi kulttuuriperinnöksi mielletty kalevalainen luontosuhde ja hengellinen luontokokemus kytketään Kalevalaan ja kansallistaitelijoihin (Ukko-Kolin ystävät).

Vaikka ulospäin myydyssä Karjala-kuvassa korostuu usein kansallisromantiikka, on alueen kulttuurikohteissa, kuten Parppeinvaaran runokylässä, Pielisen ulkoilmamuseossa ja Möhkön ruukkimuseossa, avattu myös kulttuurista luontosuhdetta. Kaksi ensin mainittua kohdetta ovat Pohjois-Karjalan biosfäärialueen yhteistyökumppaneita. Museoissa luontosuhteen paikalliset representaatiot ja niiden suhde elinkeinoon tulevat esille voimakkaammin kuin yleisessä matkailupuheessa: museoissa esiteltävä metsätyöperinne, savotat ja ruukkielämä eivät suoraan istu eksoottisen karjalaisuuden tarinaan. Etenkin Möhkön ruukkimuseon ja Petkeljärven kansallispuiston muodostama matkailualue hyödyntää vahvasti kulttuurista luontoa ja sen vaikutusta paikalliseen elämään. (Ilmolahti, ym., 2018; Lähteenmäki, Ilmolahti \& Colpaert, 2019; Tiedonanto Jansson.) 
Matkailijoiden kerrotaan 1800- ja 1900-lukujen taitteessa seuranneen taiteilijoita, ja tämän päivän matkailuun tuotetun aineiston perustella on pääteltävissä, että sama ajatus pätee osin edelleen. On kuitenkin todennäköistä, että hyvinvointiluontoa, kokemuksellisuutta ja kestävyyttä arvostavat matkailijapolvet viehättyisivät myös ruohonjuuritason tarinoiden Karjalasta, jossa luonto nähdään elinympäristönä, ei vain kansallisen katseen kohteena.

\section{Kansallisesta katseesta kohti paikallisia luontomerkityksiä?}

Tässä artikkelissa on arvioitu kulttuurisen luonnon roolia Pohjois-Karjalan biosfäärialueella matkailua varten tuotetussa historiakuvassa. Kulttuurista luontoa voidaan pitää museaalisena elementtinä, joka lisää kohteiden kiinnostavuutta ja elämyksellisyyttä. Matkailua varten sanallistettu ja merkitty kulttuurinen luonto on eräänlainen luontomuseo, joka voimistaa paikallisia historiakuvia. Etenkin kansallispuistot ovat perustamisestaan lähtien olleet sivistyshistoriallisia näytteitä, joiden tarkoitus on representoida entisaikojen ihmisen elinympäristöä. Metsäluonto edustaa alueen menneisyyttä, ja paikallisten luontoon liittyvien merkitysten hyödyntäminen historiakulttuurin rakennusaineena tuo kerrontaan syvyyttä, koska paikallinen menneisyyskuva on elimellisesti sidoksissa luonnonympäristöön.

Paikallisen historiakulttuurin rakentamiseen kytkeytyy edelleen vahvasti rajaseutuidentiteetti ja menetettyjen alueiden perintö. Pohjois-Karjalan biosfäärialueen kuntien historiakuva mukailee kansallista tarinaa. Matkailijoiden oletetaan hakevan kansallismaisemaa, eksotiikkaa ja kalevalaisia laulumaita. Tämän kuvan rakentaminen oli voimakasta elämysmatkailun syntyaikoihin 1920-luvulla. Toisen maailmansodan jälkeen erämaaromantiikan, runokarjalaisuuden ja kalevalaisuuden ylläpitäminen vakiintui keskeiseksi osaksi Pohjois-Karjalan itseymmärrystä matkailun noustessa alueella keskeiseksi elinkeinoksi. Alue on historiakulttuurin näkökulmasta ensisijassa kansallisen katseen kohteena, ja paikallinen kulttuuri tuntuu usein muokkautuvan tämän tarpeen mukaisesti.

Autenttisuuden arvioiminen on matkailua varten luoduissa maailmoissa keskeistä. Oleellisinta on se, ilmentääkö kulttuurinen luonto niitä merkityksiä, joita sen halutaan välittävän. Karjalassa aihe on erityisen jännitteinen, koska alue on saanut poikkeuksellisen suuren sijan kansallisessa kuvastossa. Paikallista menneisyyskuvaa tarkastellaan kansallisromanttisen linssin läpi: 1800-luvulla ja sen jälkeen luodut käsitykset kalevalankarjalaisuudesta estävät katseen pääsemisen paikallisen menneisyyden ominaispiirteisiin, ulos kehystetystä maisemataulusta. Omaa erityisyyttä lähestytään kansallistaitelijoiden silmin, ja karelianismia tuotteistetaan uudelleen 2010-luvun eläväksi perinnöksi. Aitta, jossa Sibelius on yöpynyt, saa merkityksensä satunnaisesta vieraasta, ja ympäristö saa merkityksensä aitasta, jonka sen erityisyyden tulkki on kosketuksellaan pyhittänyt. Kolia, pyhää vuorta, myydään taiteilijoiden Kolina, ei niinkään paikallisille merkityksellisenä luonnonpaikkana. Geologisen menneisyyden tarina kulkee karelianistisen kuvaston rinnalla korostaen sekin alueen myyttisyyttä.

Luonnonympäristön historiallinen ja kulttuurinen merkitys Pohjois-Karjalassa on kiistaton. Sillä on keskeinen sija etenkin biosfäärialueen matkailussa ja historiakulttuurissa. Myös elämyksellisyyden ja kokemuksellisuuden näkökulmasta luonnonympäristö tuo historiakulttuuriin selkeää lisäarvoa, kun luonnossa liikkumiseen liittyvä kehollisuus ja elämyksellisyys on mahdollista yhdistää historiallisiin tarinoihin. Yhteisöllisyyden ja paikallisuuden kannalta on 
oleellista, vastaako ulospäin myytävä, kyltein merkitty ja infotauluin avattu menneisyyskuva paikallisten kokemusta. Koska tutkittavana oleva alue on jo suhteellisen kauan pitänyt turismia yhtenä merkittävimmistä elinkeinoistaan, on siellä totuttu muokkaamaan historiakuvaa matkailijoiden tarpeisiin.

Merkitysanalyysissä käytettävä objektin kuntoon ja edustavuuteen viittaava ideaalitilan määritelmä on olennainen tarkasteltaessa luonnon merkitystä historiakulttuurin osana. Luonto on jatkuvasti muuttuva kokonaisuus, ja siitä, miten paljon ihminen saisi puuttua luontomuseoiden todellisuuteen, keskustellaan jatkuvasti. Ideaalitila riippuu siitä, kenen todellisuutta museaalisen luonnon toivotaan representoivan: metsästäjä-keräilijän, metsää raivaavan talonpojan vaiko ehkä metsässä karjaansa hoitavan pientilallisen. Maisemanhoito, kaskeaminen ja perinnelajien ylläpitäminen edustavat myöhempää historiaa kuin kansallispuistopioneerien tarkoittama neitseellinen erämaaluonto, mutta ne myös kiinnostavat matkailijoita ja mahdollistavat elämyksellisen osallistumisen kulttuurisen luonnon hoitamiseen. Ne ovat helposti samastuttavaa hiljattain poistuneiden sukupolvien historiaa verrattuna esimerkiksi metsään peittyneisiin kivikautisiin asuinpaikkoihin.

Luonnonympäristö on mitä suurimmassa määrin hyödynnettävissä kulttuurimatkailuun, ja historiakulttuurin voidaan katsoa olevan merkityksellinen myös luontomatkailijoille. Kulttuuriseen luontoon liittyvät tarinat ja tiedot lisäävät paikan elämyksellisyyttä. Nämä kaksi elementtiä yhdistämällä voidaan tavoittaa laajempia ihmisryhmiä kuin puhumalla yksinomaan luonnossa patikoimisesta tai perinteisestä kulttuurimatkailusta. Tieto ihmisen historiasta tai ihmisen jäljet luonnossa lisäävät elämyksen intensiteettiä. Vaikka opittu ja omaksuttu historiakulttuuri vaikuttaa luonnossa koettuun menneisyyskuvaan, on se henkilökohtaiseen kokemukseen yhdistyneenä monisyisempi kuin tuotettu kansallinen tarina. Eräässä retkikertomuksessa elämyksellinen retkeily kansallispuistossa linkittyy suhteeseen koko biosfäärin kanssa:

Yön jo laskeuduttua kuvaan vielä päivän päätteeksi kirkasta tähtitaivasta. Otava saa pääroolin monessa otoksessa. Tykkylumiset korkeat puut ovat kuin valkeita muistomerkkejä tummansinisen, pilkullisen taivaan alla. Yksi kirkkaimmista - Pohjantähti, taivaan napa - saa minut hetkeksi heittäytymään hankeen seljälleen. (Kansallispuistokeruu, s. 388)

Vaikka kokemus on henkilökohtainen, se edellyttää kulttuurista tietoa ihmisen taivaankappaleille antamista merkityksistä. Ihminen on osa biosfääriä, ja ilmastonmuutoksen herkistämässä maailmassa tämä tosiasia korostuu entisestään.

\section{Lähteet}

\section{Kirjallisuus}

Ahonen, S. (2018). Kansalliset myytit katoavana historiakulttuurina. Ennen ja nyt, 2/2018. Haettu 28.2.2019 sivulta http://www.ennenjanyt.net/2018/09/kansalliset-myytit-katoavana-historiakulttuurina/

Aineeton kulttuuriperintö. Kalevalainen luontosuhde. Haettu 29.1.2018 osoitteesta https://wiki. aineetonkulttuuriperinto.fi/wiki/Kalevalainen_luontosuhde 
Anttila, A. (2005). Loma tehtaan varjossa: Teollisuustyöväestön loma- ja vapaa-ajan moraalisäätely Suomessa 1930-1960-luvuilla. Helsinki: Suomalaisen Kirjallisuuden Seura.

Aronsson, P. (2000). Makten över minnet: Historiekultur i förändring. Lund: Studentlitteratur.

Aronsson, P. (2004). Historiebruk - att använda det förflutna. Lund: Studentlitteratur.

Beck, U. (1990). Riskiyhteiskunnan vastamyrkyt. (Suom. H. Lempa.) Tampere: Vastapaino.

Björn, I. (2012). Miten Ilomantsista tuli Ilomantsi? Teoksessa S. Knuuttila, H. Järviluoma,

A. Logrén \& R. Turunen (toim.), Syrjäseudun idea - Kulttuurianalyysejä Ilomantsista (s. 60-66). Helsinki: Suomalaisen Kirjallisuuden Seura.

Brander, U. (1927). Raja-Karjala. Suomen matkailijayhdistyksen vuosikirja 1927, 62-75.

Byrne, D. (2013). Engaging culture and nature. Teoksessa S. Brockwell, D. Byrne \& S. O'Connor (toim.), Transcending the culture-nature divide in cultural heritage: Views from the Asia-Pacific region (s. 1-12). Canberra: Australian National University.

Edelheim, J. (2017). Matkailunähtävyys. Teoksessa J. Edelheim \& H. Ilola (toim.), Matkailututkimuksen avainkäsitteet (s. 53-58). Rovaniemi: Lapland University Press.

Edensor, T. (2001). Walking in the British countryside: Reflexivity, embodied practices and ways to escape. Teoksessa P. Macnaghten \& J. Urry (toim.), Bodies of nature (s. 81-106). London: Sage.

Grönholm, P. \& Sivula A. (2010). Mitä meillä on jäljellä? Teoksessa P. Grönholm \& A. Sivula (toim.), Medeiasta pronssisoturiin: Kuka tekee menneestä historiaa? (s. 11-20). Turun historiallinen yhdistys.

Haila, Y. (2004). Retkeilyn rikkaus: Luonto ympäristöhuolen aikakaudella. Helsinki: Taide.

Hallikainen, V., Sievänen, T., Tuulentie S. \& Tyrväinen, L. (2014). Luonto kokemusten ja elämysten lähteenä. Teoksessa L. Tyrväinen, M. Kurttila, T. Sievänen \& S. Tuulentie (toim.), Hyvinvointia metsästä (s. 36-47). Helsinki: Suomalaisen Kirjallisuuden Seura.

Hemming, R. (1989). Saksalaiset ovat Suomen matkailuelinkeinon suurin mahdollisuus. Matkailusilmä, 1/1989, 6-7.

Hildén, I. (1927): Luonnonsuojelutyö Suomessa: Mietteitä uuden eduskuntaesityksen johdosta. Suomen puu: Suomen puutavara-ja paperimiesten äänenkannattaja, 5/1927, 57-60.

Hotanen, J. (2010). Merleau-Ponty ja ruumiillinen subjekti. Teoksessa T. Miettinen, S. Pulkkinen \& J. Taipale (toim.), Fenomenologian ydinkysymyksiä (s. 134-148). Helsinki: Gaudeamus.

Hovi, T. (2017). Kulttuurimatkailu. Teoksessa J. Edelheim \& H. Ilola (toim.), Matkailututkimuksen avainkäsitteet (s. 64-69). Rovaniemi: Lapland University Press.

Hultin, H. (1927). Kolinvaara ja Pamilonkoski, kaksi Pohjois-Karjalan nähtävyyttä. Finlandia, 1/1927, 190-198.

Huttunen A. (9.7.2014). Koli, Mustarinta - niin paljon enemmän kuin kansallismaisema. Haettu 8.1.2018 osoitteesta https://retkipaikka.fi/mustarinta-koli-niin-paljon-ennemman-kuin-kansallismaisema/

Hämeen-Anttila, V. (1922). Koli ja tulevaisuus. Maailma, 9/1922. 
Häyhä, H., Jantunen, S. \& Paaskoski, L. (2015). Merkitysanalyysimenetelmä. Helsinki: Suomen Museoliitto. Haettu 12.2.2019 osoitteesta https://www.museoliitto.fi/doc/Merkitysanalyysimenetelma1.pdf

Ilmolahti, O. Lähteenmäki, M., Karhu, J. \& Osipov, A. (2018). Vihreä museo: Paikallisuus, identiteetti ja ekomuseoliike. Elore, 25(2), 100-127. https://journal.fi/elore/article/view/77208/38469

Ilmonen, K. (2016). Kulttuuriperintö maaseudun matkailuyritysten tuotteissa ja palveluissa. Jyväskylän yliopisto, Kokkolan yliopistokeskus Chydenius.

Ilomantsi. Pogostan pitäjä. Haettu 29.1.2018 osoitteesta http://www.ilomantsi.fi/pogostan-pitaja

Kalela, J. (2010). Historian rakentamisen mieli ja tutkijan valinnat. Teoksessa P. Grönholm \& A. Sivula (toim.), Medeiasta pronssisoturiin: Kuka tekee menneestä historiaa? (s. 40-59). Turun historiallinen yhdistys.

Kallinen, T., Nygren, A. \& Tammisto, T. (2012). Luonto-kulttuuri-jaotteluista tilanteellisiin luontosuhteisiin. Teoksessa T. Kallinen, A. Nygren ja T. Tammisto (toim.), Ympäristö ja kulttuuri (s. 9-35). Helsingin yliopisto.

Kalliola, R. (1953). Alkusanat. Suomen Luonto, 1/1953, 6-7.

Kalliola, R. (1954). Matkailu ja retkeily luonnonsuojelun näkökulmasta. Suomen Luonto, 1/1954, 9-21.

Kareliabiosphere. Mitä biosfäärialueet ovat? Haettu 5.6.2019 osoitteesta http://www.kareliabiosphere.fi/in-finnish/etusivu/mit\%C3\%A4-biosfaarialueet-ovat/

Karhukorva, R., Kärkkäinen, S. \& Paaskoski, L. (2017). Metsäsuhteiden kenttä. Punkaharju: Lusto. Haettu 26.2.2019 osoitteesta https://issuu.com/luston_julkaisuja/docs/metsasuhteiden_kentta

Karjalainen P. T. (2007). Paikoista maisemiin: Ympäristön eletty mieli. Teoksessa Y. Sepänmaa, L. Heikkilä-Palo \& V. Kaukio (toim.), Maiseman kanssa kasvokkain (s. 50-57). Helsinki: Maahenki.

Karu Survival. Haettu 11.2.2019 osoitteesta https://www.karusurvival.com/fi/etusivu

Karvinen, T. (2018). Kansallispuistot: Maamme luonnon helmet. Jyväskylä: Docendo.

Kettunen, M. (7.2.2019). Pohjois-Karjala - Euroopan itäisin erämaa. Haettu 11.2.2019 osoitteesta https://retkipaikka.fi/pohjois-karjala-euroopan-itaisin-eramaa/

Knuuttila S. \& Piela, U. (2014). Ympäristömytologia - havainto ja tulkinta. Teoksessa S. Knuuttila \& U. Piela (toim.), Ympäristömytologia (s. 7-20). Helsinki: Suomalaisen Kirjallisuuden Seura.

Koju Film Company. (2014). Mustarinta. A Film about Koli. Haettu 8.1.2018 osoitteesta Koli-filmi, https://kojufilm.com/mustarinta-a-film-about-koli/

Kumpulainen. J., Laiho, J. \& Pirinen, M. (2007). Petkeljärvi-Putkelanharjun ja Puohtiinsuon Natura 2000 -alueiden hoito-ja käyttösuunnitelma. Vantaa: Metsähallitus.

Laukkanen, M. (2010). Kolin-Ruunaan alueen luontomatkailusuunnitelma. Vantaa: Metsähallitus.

Laurén, K. (2015). Kokemuksia Kolin kansallispuistosta ja -maisemista. Menneisyyden kertomukset nykypäivän luontokokemusten muokkaajina. Elore, 22(2). http://www.elore.fi/arkisto/2_15/lauren.pdf 
Lehto-Vahtera, J. (2015). Henkilömuseo on merkitysten koti. Teoksessa H. Häyhä, S. Jantunen \& L. Paaskoski (toim.) Merkitysanalyysimenetelmä (s. 39-42). Helsinki: Suomen Museoliitto. Haettu 12.2.2019 osoitteesta https://www.museoliitto.fi/doc/Merkitysanalyysimenetelma1.pdf

Leppänen, M \& Pajunen, A. (2017). Terveysmetsä: Tunnista ja koe elvyttävä luonto. Helsinki: Gummerus.

Lieksan kaupunki. Lieksan historiaa ja nykypäivää (kirjoittanut Asko Saarelainen). Haettu 29.1.2019 osoitteesta https://www.lieksa.fi/documents/89419/364323/Lieksan+historiaa+ja+nykyp\%C3\%A4iv\%C3\%A4\%C3\%A4+-+Asko+Saarelainen.pdf/d2c995co-740f-1fc4-8d8d-5f8eb616agb7

Linkola, K. (1926). Suunnitelma luonnonsuojelualueiden erottamiseksi Pohjois-Suomen valtionmailla. Silva Fennica, 1/1926.

Linkola, K. (1927). Luonnonsuojelualueistamme. Hakkapeliitta, 29/1927, 17-19.

Luontoon.fi. Kansallispuistot - Upeinta Suomea. Haettu 29.1.2018 osoitteesta https:/www.luontoon.fi/kansallispuistot

Lusto (2015). Luston kokoelmapolitiikka. Punkaharju: Suomen Metsämuseo. Haettu 26.2.2019 osoitteesta http://www.lusto.i/wp-content/uploads/Luston_kokoelmapolitiikka_2015_julk.pdf

Lähde, V. (2005). Luonnonkatastrofin luonto. nüin\&näin, 12(1), 31-34.

Lähteenmäki, M., Ilmolahti, O. \& Colpaert, A. (2019). Represented nature: Environmental dialogue in the Finnish-Karelian historical museums. (Submitted manuscript.)

Martikainen, M. (2011). Kilpalaulanta kalevalaisesta perinteestä. Ilomantsin ja Kuhmon kuntien oikeus kalevalaisen perinteen matkailulliseen hyödyntämiseen puhunnassa ja toteutuksessa. Pro gradu -tutkielma. Itä-Suomen yliopisto, Yhteiskuntatieteiden ja kauppatieteiden tiedekunta, Suomen historia.

Martikainen, I., Kullberg, S. \& Lovén, L. (2006). Kolin kansallispuiston luontopolut: Kasken kierros. Koli: Metsäntutkimuslaitos. Haettu 5.6.2019 osoitteesta https://julkaisut.metsa.fi/assets/pdf/ lp/Muut/kolikasreittiopas.pdf

Miettunen, K. (2009). Menneisyys ja historiakuva: Suomalainen kuusikymmentäluku muistelijoiden rakentamana ajanjaksona. Helsinki: Suomalaisen Kirjallisuuden Seura.

Monola-seura. Haettu 29.1.2019 osoitteesta https://www.monola.fi/seurasta

Möhkön ruukki. Möhkön tomina 1882. Haettu 12.11.2018 osoitteesta http://www.mohkonruukki. fi/fi/m\%C3\%B6hk\%C3\%B6n-ruukki-4/245-m\%C3\%B6hk\%C3\%B6n-tarinat-4

Paasi, A. (1986). Neljä maakuntaa: Maantieteellinen tutkimus aluetietoisuuden kehittymisestä. Joensuun yliopisto.

Paaskoski, L. (2015) Lyylin puuloota - merkitysanalyysi esineen tulkinnassa. Artefactum, 6. Haettu 12.2.2019 osoitteesta http://www.artefacta.fi/tutkimus/artefactum/6

Palmgren, R. (1922). Luonnonsuojelu ja kulttuuri I-II. Helsinki: Otava.

Parppeinvaaran runokylä. Haettu 18.2.2019 osoitteesta http://www.parppeinvaara.fi 
Pekurinen, M. (1997). Sivistys velvoittaa: Klassinen luonnonsuojelu Suomessa. Teoksessa H. Roiko-Jokela (toim.), Luonnon ehdoilla vai ihmisen arvoilla? Polemiikkia metsien suojelusta 1850-luvulta 1990-luvulle (s. 129-166). Jyväskylä: Atena.

Perttula, M. (2006). Suomen kansallispuistojärjestelmän kehittyminen 1960-1990-luvuilla ja U.S. National Park Servicen vaikutukset puistojen hoitoon. Vantaa: Metsähallitus.

Petrisalo, K. (2001). Menneisyys matkakohteena: Kulttuuriantropologinen ja historiatieteellinen tutkimus perinnekulttuurien hyödyntämisestä matkailuteollisuudessa. Helsinki: Suomalaisen Kirjallisuuden Seura.

Pihlman, S. (2007). Museo ja ympäristö. Teoksessa P. Kinanen (toim.), Museologia tänään (s. 210234). Helsinki: Suomen museoliitto.

Piitulainen, H. (2014). Patikkapoluilta Korpiselkä-taloon: Tuupovaaran matkailun kehittäminen 1960- ja 1980-luvuilla. Pro gradu -tutkielma. Itä-Suomen yliopisto, Historia- ja maantieteiden laitos.

Pohjois-Karjalan maakuntaliitto (2014). Pohjois-Karjalan matkailun teema-ja toimenpideohjelma 2014-2020. Joensuu: Pohjois-Karjalan maakuntaliitto.

Raivo, P. J. (2007). Menneisyys ja perinne kulttuurimatkailun resurssina. Teoksessa S. Knuuttila \& U. Piela, Menneisyys on toista maata (s. 269-286). Helsinki: Suomalaisen Kirjallisuuden Seura.

Rantala, J. (2012). Lapset historiakulttuurin kuluttajina. Helsinki: Historiallis-yhteiskuntatiedollisen kasvatuksen tutkimus- ja kehittämiskeskus.

Rantala, O. (2017). Luontomatkailu. Teoksessa J. Edelheim \& H. Ilola (toim.), Matkailututkimuksen avainkäsitteet (s. 59-63). Rovaniemi: Lapland University Press.

Richardson, M. (2001). The experience of culture. London: Sage.

Ricœur, P. (2000). La mémoire, l'histoire, l'oubli. Paris: Éditions du Seuil cop.

Rosberg J. E. (1927). Karjala. Suomen matkailijayhdistyksen vuosikirja 1927, 7-17.

Russel, R. \& Winkworth, K. (2009). Significance 2.0: A guide to assessing the significance of collections. Collection Council of Australia. Haettu 3.6.2019 osoitteesta https://www.arts.gov.au/sites/g/ files/net1761/f/significance-2.0.pdf

Saari, J. (25.9.2017). Esittelyssä Tea Karvisen näyttävä uutuusteos: Kansallispuistot - maamme luonnon helmet. Haettu 28.2.2019 osoitteesta https://retkipaikka.fi/vapaa/esittelyssa-tea-karvisen-nayttava-uutuusteos-kansallispuistot-maamme-luonnon-helmet/

Saarinen, J. (2005). Luontomatkailun kehittäminen ja tutkimus Suomessa. (Metlan työraportteja 52.) Haettu 11.1.2019 osoitteesta http://www.metla.fi/julkaisut/workingpapers/2005/mwpo20-14. pdf

Salmi, H. (2001). Menneisyyskokemuksesta hyödykkeisiin - historiakulttuurin muodot. Teoksessa J. Kalela \& I. Lindroos (toim.), Jokapäiväinen historia (s. 134-149). Helsinki: SKS.

Seppä, T. (2015). Kohtaamisia menneen kanssa: Tutkimus kansanrunousaineistojen synnystä ja myöhemmistä tulkinnoista. Joensuu: Suomen Kansantietouden Tutkijain Seura. 
Similä, M., Tervonen, A. \& Tuhkalainen, K. (2006). Koitajoen Natura-alueen hoito- ja käyttösuunnitelma. Helsinki: Metsähallitus.

Soini, Y. (1950). Ajatuksia luonnon- ja kansallispuistojen merkityksestä: Tieteen- ja kulttuurialojen edustajien lausuntoja. Suomen Luonto, 1/1950, 15-16.

Sulopuisto, S. (2018). Pohjois-Karjalan Matkailu ry - 125 vuotta aatteellista matkailutyötä Pohjois-Karjalassa. Joensuu: Pohjois-Karjalan Matkailu ry.

Suunnitelma uusiksi luonnon- ja kansallispuistoiksi. Suomen Luonto, 1/1948, 9-33.

Syrjämaa, T. (2004). Aurinkoa ja lunta: Muuttuvat matkailutottumukset. Teoksessa A. Kostiainen, J. Ahtola, L. Koivunen, K. Korpela, \& T. Syrjämaa, Matkailijan ihmeellinen maailma: Matkailun historia vanhalta ajalta omaan aikaamme (s. 172-186). Helsinki: Suomalaisen Kirjallisuuden Seura.

Söyrinki, N. (1957). Luonnonsuojelumme saavutuksia ja tavoitteita. Suomen Luonto, 1/1957, 1-27.

Taivainen, J. (2010). Lieksa Ruunaan alue: Kulttuuriperintökohteiden inventointi / KMO (00343). Vantaa: Metsähallitus. Haettu 13.6.2019 osoitteesta https://julkaisut.metsa.fi/assets/pdf/mt/ kmo-lieksa-ruunaa.pdf

Taivainen, J. (toim.) (2016). Metsiin kadonneet - Valtion metsien kulttuuriperintökohteiden inventointihanke 2010-2015. Vantaa: Metsähallitus.

Turunen, H. (2010). Hämärätunnin tarinoita. Helsinki: WSOY.

Turunen, H. \& Turunen, R. (1997). Pielisen kirja: Kansallismaisema kahden taiteilijan elämänä. WSOY: Porvoo, Helsinki, Juva.

Tyrväinen L. \& Tuulentie S. (2007). Luontomatkailun tutkimus laajenee, moninaisuus lisääntyy. Teoksessa L. Tyrväinen \& S. Tuulentie (toim.), Luontomatkailu, metsät ja hyvinvointi (s. 5-13). (Metlan työraportteja 52.) Helsinki. Haettu 3.1.2019 osoitteesta http://www.metla.fi/julkaisut/ workingpapers/2007/mwp052-02.pdf

Unesco. Man and the Biosphere Programme. Haettu 13.6.2019 osoitteesta http://www.unesco. org/new/en/natural-sciences/environment/ecological-sciences/

Ukko-Kolin ystävät. Luontorauha - Pax Natura. Haettu 29.1.2018 sivulta https://www.ukko-kolinystavat.fi/media/Ystavien\%20tiedotteet/ESITE\%20Luontorauha\%2024_6_2017_\%20doc.pdf

van der Duim, R. (2005). Tourismscapes: An actor-network perspective on sustainable tourism development. Dissertation, Wageningen University.

Vilkuna, K. (1950). Ajatuksia luonnon- ja kansallispuistojen merkityksestä: Tieteen- ja kulttuurialojen edustajien lausuntoja. Suomen Luonto, 1/1950, 13.

von Bonsdorff, P. (2007). Maisema toiminnan ja kuvittelun tilana. Teoksessa Y. Sepänmaa, L. Heikkilä-Palo \& V. Kaukio (toim.), Maiseman kanssa kasvokkain (s. 33-49). Helsinki: Maahenki.

Wartiainen, E. (1927). Laatokan pohjoisrannikko, Valamo ja Raja-Karjala. Finlandia, 1/1927, 139182.

Williams, R. (2003). Luontokäsitykset. Teoksessa Y. Haila \& V. Lähde (toim.), Luonnon politiikka (s. 40-66). Tampere: Vastapaino. 
Ympäristöministeriö (2014). Fennoskandian vihreä vyöhyke. Haettu 23.1.2019 osoitteesta http:// www.ym.fi/fi-FI/Kansainvalinen_yhteistyo/Fennoskandian_vihrea_vyohyke/Luonto_ja_kulttuuri

\section{Alkuperäislähteet}

Suomalaisen Kirjallisuuden Seuran kansanrunousarkiston Joensuun perinnearkisto (SKS JPA) Kansallispuistokeruu 2013

Metsämuseo Lusto

Metsähallituksen metsätalouden kulttuuriperintöinventointikokoelman valokuvat (Jouni Taivainen)

Työväenmuseo Werstas

SLL kansallispuistonäyttelyn 1980 julisteet

\section{Lively border -hankkeen aineisto}

Vihreä museo -verkkokysely 2017

Haastattelut ja tiedonannot

Lasse Lovénin haastattelu 27.6.2017 (Jani Karhu)

Kyösti Tuhkalaisen sähköpostihaastattelut 12.9.2017 ja 23.9.2017 (Jani Karhu)

Sirkka Kuikan puhelinhaastattelu 7.1.2019 (Oona Ilmolahti)

Asta Janssonin sähköpostitiedonanto Oona Ilmolahdelle 9.1.2019 